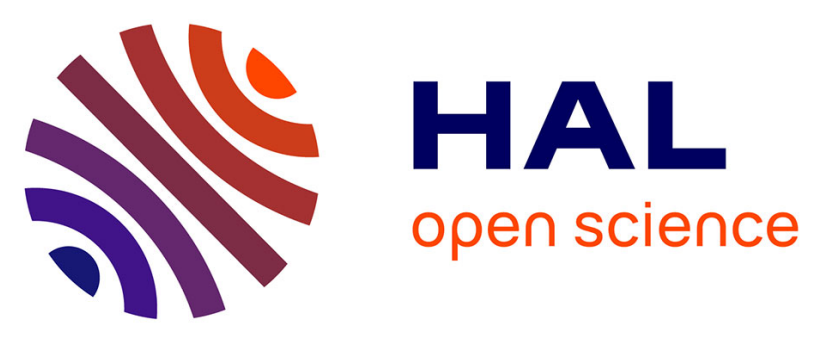

\title{
Geochemical investigation of the taphonomy, stratigraphy, and palaeoecology of the mammals from the Ouled Abdoun Basin (Paleocene-Eocene of Morocco)
}

Lászl Kocsis, Alex Ulianov, Mustapha Mouflih, Fatima Khaldoune, Emmanuel Gheerbrant

\section{To cite this version:}

Lászl Kocsis, Alex Ulianov, Mustapha Mouflih, Fatima Khaldoune, Emmanuel Gheerbrant. Geochemical investigation of the taphonomy, stratigraphy, and palaeoecology of the mammals from the Ouled Abdoun Basin (Paleocene-Eocene of Morocco). Palaeogeography, Palaeoclimatology, Palaeoecology, inPress, 577, pp.1-17. 10.1016/j.palaeo.2021.110523 . hal-03269557

\section{HAL Id: hal-03269557 \\ https://hal.science/hal-03269557}

Submitted on 24 Jun 2021

HAL is a multi-disciplinary open access archive for the deposit and dissemination of scientific research documents, whether they are published or not. The documents may come from teaching and research institutions in France or abroad, or from public or private research centers.
L'archive ouverte pluridisciplinaire HAL, est destinée au dépôt et à la diffusion de documents scientifiques de niveau recherche, publiés ou non, émanant des établissements d'enseignement et de recherche français ou étrangers, des laboratoires publics ou privés. 
Geochemical investigation of the taphonomy, stratigraphy, and palaeoecology of the mammals from the Ouled Abdoun Basin (Paleocene-Eocene of Morocco)

${ }^{1}$ Geology Group, Universiti Brunei Darussalam (UBD), Brunei Darussalam, email: laszlokocsis@hotmail.com

${ }^{2}$ Institute of Earth Sciences, University of Lausanne, Switzerland, email: alexey.ulyanov@unil.ch

${ }^{3}$ Hassan II University of Casablanca, Sedimentary Basins Dynamic and Geological Correlations Lab, Casablanca, Morocco, email: moufli@yahoo.fr

${ }^{4}$ Groupe Office Chérifien des Phosphates, Centre Minier de Khouribga, Morocco, email: khaldoune.fatima@ocpgroup.ma

${ }^{5} \mathrm{CR} 2 \mathrm{P}$, Sorbonne Université, CNRS-MNHN-UPMC, Paris, France, email: emmanuel.gheerbrant@mnhn.fr

*corresponding author: laszlokocsis@hotmail.com, laszlo.kocsis@ubd.edu.bn

\section{ABSTRACT}

We performed different geochemical analyses of Paleogene terrestrial mammal remains to establish their taphonomy, stratigraphic provenance, and palaeoenvironmental conditions. Rare earth element (REE) results indicate a similar diagenetic history to that of previously investigated marine taxa from these beds. Therefore, the mammal remains were initially deposited in a marine setting, and probably not long after the death of the animals their bodies were washed into the sea. The $\mathrm{Ce} / \mathrm{Ce}$ * and $\mathrm{Pr} / \mathrm{Pr}$ * ratios for the mammal fossils were compared with the background dataset from the phosphate mines, which varies with time. This allowed us to characterize the stratigraphic levels bearing the fossils. The provenances of fossils with known origins were confirmed, while remains with unknown origins could be assigned to certain stratigraphic horizons that are compatible with previously proposed phylogenic relationships. 
Marine diagenesis affected the various skeletal tissues differently, with the largest alteration in the bone and the least or none in the enamel. This is mostly demonstrated by the high $\mathrm{F}$ concentration, high $\mathrm{Ca} / \mathrm{P}$, and seawater related ${ }^{87} \mathrm{Sr} /{ }^{86} \mathrm{Sr}$ in the bone/dentine samples. Enamel shows the opposite, and retained the most pristine terrestrial values. The $\delta^{18} \mathrm{O}_{\mathrm{PO} 4}$ and $\delta^{13} \mathrm{C}$ results from mammal enamel revealed warm $\left(>20^{\circ} \mathrm{C}\right.$ mean annual temperature-MAT) and dry ( $<500 \mathrm{~mm}$ mean annual precipitation) conditions for PaleoceneEocene period in the region. From the early to mid-Ypresian about $+5^{\circ} \mathrm{C} \Delta \mathrm{MAT}$ is recorded that might be linked to the Early Eocene Climatic Optimum.

Furthermore, the ${ }^{87} \mathrm{Sr} /{ }^{86} \mathrm{Sr}$ ratios derived from shark tooth enameloid fit the global open ocean Sr-isotope record during the latest Paleocene and early Eocene providing further evidence for the age of these phosphate beds in the Ouled Abdoun Basin. However, older marine fossils yielded higher ratios than the global Sr-isotope curve, reflecting an alteration and/or somewhat restricted conditions in the Moroccan coastal basins, possibly triggered by global sea-level changes.

Keywords: bioapatite, rare earth elements, stable isotopes, strontium isotopes, phosphorite.

\section{Introduction}

The phosphate series of the Ouled Abdoun Basin in Morocco, which is exploited in large industrial quarries, is renowned for its Upper Cretaceous-Lower Eocene vertebrate assemblages (e.g., Arambourg, 1952; Bardet et al., 2017). The fauna predominantly comprises sub-autochthonous marine aquatic organisms such as cartilaginous and bony fishes, mosasaurs, and turtles, but occasionally terrestrial remains have also been described, such as non-avian dinosaurs, birds, and mammals (e.g., Gheerbrant et al., 2003; Pereda Suberbiola et al., 2004; Bourdon et al., 2005). The mammals are rare and most of the time scientists come to know about them from private collectors living near the phosphate quarries, and often cannot determine their precise stratigraphic origin. Knowing the stratigraphic origins of the Ouled Abdoun fossils is crucial to elucidating the early Cenozoic evolution of African mammals (e.g., Gheerbrant et al., 2018). Accurate dating of the Ouled Abdoun mammals is also important for knowledge and characterization of the early Cenozoic successive African faunal assemblages. 
To tackle the stratigraphic origins of vertebrate remains, geochemical taphonomy is a widely used method (e.g., Staron et al., 2001; Trueman et al., 2003; Metzger et al., 2004; MacFadden et al., 2007; Suarez et al., 2010; Herwartz et al., 2013; Botfalvai et al., 2021). This is based on trace element contents that are absent or occur only in very low concentrations (sub-ppm) in modern bones and teeth, however, after the death of the animals their concentrations increase through the influence of the sedimentary environment (e.g., Elderfield and Pagett, 1986). The most widely used elements are the rare earths (REE) and uranium, which can reach 4-5 orders of magnitude enrichment in fossil material compared to modern concentrations (e.g., Trueman and Tuross, 2003). These elements therefore could reflect the chemistry of the pore fluid in which the vertebrate remains were fossilized. There are several studies using REE chemistry of fossil bioapatite to reconstruct palaeoenvironmental conditions in terrestrial and marine depositional settings (e.g., Trueman et al., 2003; Lécuyer et al. 2004; Shield and Webb, 2004; Kocsis et al., 2009; Žigaitè et al., 2016; 2020), which are all based on the assumption that REEs are quantitatively taken up from the burial environment (e.g., Reynard et al., 1999). During their incorporation into the bioapatite structure, however, fractionation could occur between the light and heavy REEs due to size differences along the REE series and related diffusion (e.g., Trueman et al., 2011; Herwartz et al., 2013). In addition, protracted late diagenetic modification (Kocsis et al., 2010; Herwartz et al., 2011) may further complicate environmental interpretations, especially for older samples (Kowal-Linka et al., 2014). To address these issues, a large number of samples, including different types of materials (e.g., bones, teeth, enamel, and dentine), and multiple in-situ analyses, are needed to evaluate further the origin of the REEs within the bioapatite.

In relation to the Moroccan phosphate series in the Ouled Abdoun and Ganntour basins, the trace element chemistry of nearly 200 marine samples (fish teeth, bones, coprolites) was published in Kocsis et al. (2016). Fractionation and late diagenetic overprint were completely ruled out. All the samples yielded similar, typical oxic seawater REE distributions with heavy REE enrichment and a negative Ce-anomaly. Importantly, however, the Ceanomalies show a distinct change with stratigraphic level (Kocsis et al., 2016), a trend that is used in this work to assign a stratigraphic age for unprovenanced fossils. Such an approach was successful for the Embrithopoda mammal taxa of Stylolophus minor and S. major in the Ouled Abdoun Basin (Gheerbrant et al., 2018). 
The main aim of this study is to further investigate the validity of the trace element provenancing method for the rare mammal fossils with known and unknown origins in the Ouled Abdoun Basin. To help better assess the taphonomy of these remains, major and other trace elements, and strontium isotope ratios $\left({ }^{87} \mathrm{Sr} /{ }^{86} \mathrm{Sr}\right)$ of selected mammal fossils, were compared with marine end-members such as data from shark teeth. Enameloid ${ }^{87} \mathrm{Sr} /{ }^{86} \mathrm{Sr}$ data derived from the latter also provide a proxy for the age of the phosphate beds, through comparing their ratios with the global ${ }^{87} \mathrm{Sr} /{ }^{86} \mathrm{Sr}$ record. In addition, some mammal fossils were measured for their stable oxygen and carbon isotopic compositions to get an insight into the ecological conditions of some of these early African placental mammals.

\section{Geological and stratigraphical settings}

The Ouled Abdoun Basin is one of the ancient epicontinental marine basins along the Atlantic coast of Africa, where large amounts of phosphorite accumulated during the late Cretaceous - early Eocene period. The basement rocks are covered by Cenomanian-Turonian carbonates followed by yellow marls with possible age within the Coniacian-Campanian interval (El Assel et al., 2013), which were eventually succeeded by the phosphorite series. The top of the succession is either covered by Lutetian dolomitic limestone or by Neogene continental beds (OCP, 1989). In the phosphorite series, three sequences $(A-C)$ of $2^{\text {nd }}$ order transgressive-regressive (T-R) cycles (Vail et al., 1991) are recognized, with ages of Maastrichtian (latest Cretaceous) (A), Danian-Thanetian (Paleocene) (B), and Ypresian (early Eocene) (C). These T-R cycles are further divided into $3^{\text {rd }}$ order cycles that begin with P-rich phosphate (often granular in appearance), and end with clayey, carbonate, or siliceous deposits. The phosphorite series is often followed by a fourth sequence (D) but without phosphate occurrences (EL Haddi, 2014), marking the reduction of phosphogenesis and the installation of silicified limestone with lumachellic texture and the occurrence of Thersiteatype gastropods (Mouflih, 2015).

Regional correlation and biostratigraphy of these sediments are achieved by examining selachian remains (i.e., shark and ray teeth), which are extremely abundant (e.g., Arambourg, 1952; Noubhani and Cappetta, 1997; Cappetta et al., 2014), while other, nonphosphatic fossils are either very poorly preserved or do not have significant stratigraphic value (e.g., Ollivier-Pierre, 1982; Rauscher, 1985; Soncini, 1990). Chemostratigraphy based 
on the $\delta^{13} \mathrm{C}$ of residual organic matter (Yans et al., 2014) and the $\delta^{18} \mathrm{O}$ and $\delta^{13} \mathrm{C}$ of marine vertebrate fossils (Kocsis et al., 2014a), however, revealed some details about the timing of the Paleogene beds such as (1) sedimentation occurred during the middle Paleocene (Selandian, 61.5-59.2 Ma); (2) a possible lack of sedimentation during the latest Paleocene (late Thanetian, 57-56 Ma), probably including the Paleocene-Eocene Thermal Maximum (PETM); and (3) the third sequence (C) was deposited during the early Eocene (early - ?late Ypresian, 56-51 Ma) including the Early Eocene Climatic Optimum (EECO). into several phosphate-rich beds of industrial value (from base to top, beds III, II, I, 0) with

Traditionally, the phosphate succession in the Ouled Abdoun Basin is further subdivided the non-exploited horizons of calcareous phosphate, chert, or thin clay between them called intercalary beds (Figure 1). Bed III refers to the Late Cretaceous layers, Bed Ila and Bed IIb to the Paleocene beds, while Bed I, Bed 0', Bed 0, and the top layers called "sillons" are early Eocene, as determined from the associated selachian faunas (Arambourg, 1952; Noubhani and Cappetta, 1997) (Figure 1). Upsection the proportions of phosphate decrease and chertrich sediments occur more often. The successive phosphate beds recurrently enclose "bone beds" where vertebrate remains are concentrated, probably as a result of hydrodynamic accumulations and/or during a period of condensation of bioclastic material with a low sedimentation rate (Gheerbrant et al., 2003). Three of them also yielded unique mammal remains: (1) the Eritherium bone bed at the base of Bed Ila, dated Selandian (61.6 - 59.2 $\mathrm{Ma})$; (2) the big coprolite bone bed in the upper part of Bed Ila, dated Thanetian (59.2-56 $\mathrm{Ma}$ ); and (3) the earliest Ypresian ( 56-55 Ma) Otodus obliquus bone bed within intercalary bed II/I (Figure 1). Mammals also derived from two younger levels (Figure 1) such as (4) the base of Bed I, dated lower Ypresian ( 55-54 Ma); and (5) the upper phosphate horizons, Bed 0 and the "sillons", dated middle Ypresian ( 53-51 Ma) (Yans et al., 2014; Kocsis et al., 2014a).

The mammals recovered from these Paleocene and lower Eocene phosphate beds are the earliest known placentals in Africa, together with those from the Ouarzazate Basin (Gheerbrant et al., 2017). Despite their rarity, they document an unexpected taxonomic diversity, especially for paenungulates (Afrotheria), which comprise 7 genera and 10 species (Abounodus, Ocepeia daouiensis, O. grandis, Eritherium, Phosphatherium, Daouitherium, Seggeurius, Paenungulata indet., Stylolophus minor, S. major; see Gheerbrant et al., 1998, 2001, 2003, 2009, 2014, 2018; Bardet et al., 2017). 


\section{Material and Methods}

\subsection{Investigated materials}

Several mammal species and/or other fossils from the mammal-related sediment matrix were involved in our research. Some of the fossils have known stratigraphic positions, while the origins of the others are questionable or completely unknown (Table 1). We focused primarily on the trace element compositions of the fossils (Table 1). However, some specimens were also analyzed for the presence of major elements ( $\mathrm{Ca}, \mathrm{P}, \mathrm{F})$, stable oxygen and carbon isotopes, and radiogenic strontium isotopes. The latter taxa are Daouitherium rebouli (Bed 0), Phosphatherium escuilliei (intercalary Bed II/Bed I, and Bed I), Hyracoidea indet (unknown bed; Gheerbrant et al., 2003), Ocepeia grandis (Bed Ila; Gheerbrant et al., 2014), and Eritherium azzouzorum (base of Bed Ila, i.e., Eritherium bone bed). These mammals are mostly known by fragments of jaws and, in the best cases, by a few skulls, and all of them are early representatives of the African endemic placental ungulates (Paenungulata). In particular Eritherium (Gheerbrant, 2009, Gheerbrant et al., 2012), Phosphatherium (Gheerbrant et al., 2005), and Daouitherium (Gheerbrant et al., 2002) are the earliest and most basal proboscideans. They document the very early emergence in Africa of one of the most remarkable lineage of extant placentals, the elephant order (Gheerbrant, 2009).

Often different parts have been analyzed and compared in parallel, such as mammal tooth enamel and dentine, bone, and - from the sediment matrix - shark tooth enameloid, dentine, and coprolites. More details about the analyses of these are presented in the Methods section.

In addition, the background trace element dataset (Kocsis et al., 2016) is extended here by samples analyzed from the big coprolite bone bed (upper part of Bed Ila) from quarries of Sidi Chennane (N32 $38^{\prime} 25^{\prime \prime}, W^{\circ} 43^{\prime} 22^{\prime \prime}$ ) and Sidi Daoui (Meraa El Arech Nord - N32 $46^{\prime} 47^{\prime \prime}$, W6 $\left.6^{\circ} 45^{\prime} 4^{\prime \prime}\right)$, while a few specimens from the Eritherium and Otodus obliquus bone beds were also added from Sidi Daoui near Meraa El Arech Nord and Boujniba (N3252'16", W6 $47^{\prime} 13^{\prime \prime}$ ), respectively (Supplementary Material Table-1).

\subsection{Major and trace element compositions}


All the analyses were carried out at the Institute of Earth Sciences, University of Lausanne, Switzerland. The mammal remains (teeth and bones) and fossils from the associated matrix (fish teeth, coprolites) were cut with a micro-saw, then small pieces were embedded in epoxy resin and flat-polished. The major-element contents of selected fossils were determined by using wavelength-dispersive analysis with a JEOL 8200 microprobe. The concentrations of rare earth and other trace elements were measured by Laser AblationInductively Coupled Plasma-Mass Spectrometry (LA-ICP-MS), using a GeoLas 200M ArF excimer laser (193nm) coupled to a Perkin-Elmer ELAN 6100 DRC quadrupole spectrometer or via Element XR ICP-MS with a linked RESOlution ablation system. The ablation was carried out in a He atmosphere using spot sizes of $60-80 \mu \mathrm{m}$ in diameter. Standard reference materials 612 from NIST, representing silica-lime-alumina glasses doped with trace elements, were used for external standardization (Pearce et al., 1997). ${ }^{42}$ Ca was analyzed as an internal standard; $\mathrm{CaO}$ values of 54,51 and 50 wt.\% were used respectively for shark tooth enameloid, mammal enamel, and for more porous material such as dentine, bone and coprolites. These values are the overall average $\mathrm{CaO}$ content of the different remains derived from the microprobe data presented here (Supplementary Material Table-2) and provided in Kocsis et al. (2014a). The analytical reproducibility was generally better than $\pm 5 \%$ SE.

\subsection{Strontium isotope ratios $\left({ }^{87} \mathrm{Sr} /{ }^{86} \mathrm{Sr}\right)$}

The chemical separation of $\mathrm{Sr}$ and mass spectrometry were performed at the Department of Earth Sciences, University of Geneva (Switzerland). Selected fossils were cleaned in an ultrasonic bath to reduce any sedimentary contamination, then the external 0.5-1 $\mathrm{mm}$ surface was removed that might have been altered in the depositional environment. From the cleaned surface about 2-5 mg of mammal enamel(oid) / dentine / bone powder was obtained using a micro-drill, and was dissolved in Teflon beakers at $80^{\circ} \mathrm{C}$ in $2 \mathrm{M} \mathrm{HCl}$. Sr separation was performed by extraction chromatography using Eichrom's SrSpec resin according to a protocol modified from Pin et al. (1994). Strontium was analysed in $2 \% \mathrm{HNO}_{3}$ solution on a Neptune Plus Multi Collector ICP-MS. Interferences at masses ${ }^{84} \mathrm{Sr}$ $\left({ }^{84} \mathrm{Kr}\right),{ }^{86} \mathrm{Sr}\left({ }^{86} \mathrm{Kr}\right)$ and ${ }^{87} \mathrm{Sr}\left({ }^{87} \mathrm{Rb}\right)$ were corrected by monitoring ${ }^{83} \mathrm{Kr}$ and ${ }^{85} \mathrm{Rb}$. Mass fractionation was internally corrected assuming $a^{88} \mathrm{Sr} /{ }^{86} \mathrm{Sr}$ ratio of 8.375209 . The values were internally corrected further for external fractionation based on repeat analyses of the 
223 strontium NBS 987 standard (nominal value of 0.710248 ), which yielded an average ${ }^{87} \mathrm{Sr} /{ }^{86} \mathrm{Sr}$

224 value of 0.710270 (10 ppm long-term reproducibility, $1 \sigma)$.

3.4. Stable isotope analyses $\left(\delta^{18} O_{P O 4}, \delta^{13} \mathrm{C}, \delta^{18} O_{\text {СО3 }}\right)$

The sample preparation and analyses were performed in the Stable Isotope Laboratory of the Institute of Earth Surface Dynamics at the University of Lausanne, Switzerland. Sample preparation and some of the analytical backgrounds are summarized in Kocsis et al. (2014a). The oxygen isotope composition of $\mathrm{PO}_{4}{ }^{3-}$ ion was analysed with a high-temperature conversion elemental analyser (TC/EA) coupled to a Finnigan MAT Delta Plus XL mass spectrometer. The results were corrected to in-house $\mathrm{Ag}_{3} \mathrm{PO}_{4}$ phosphate standards (LK-2 L: $12.1 \%$ and LK-3 L: $17.9 \%$ ) with better than $\pm 0.3 \%$ o $(1 \sigma)$ standard deviations during the runs. NBS-120c phosphorite reference material was prepared in parallel with the samples and an average value of $21.6 \pm 0.3 \%$ o $(n=10)$ was obtained. The carbon and oxygen isotope compositions of the structural carbonate in the apatite were analysed with a Gasbench II coupled to a Finnigan MAT Delta Plus XL mass spectrometer. The measured isotopic ratios were normalized to an in-house Carrara marble calcite standard that is calibrated against NBS-19. The analytical precision for this method is better than $\pm 0.1 \%$ for $O$ and $C$ isotopes. The data are expressed in delta notation, in the case of $\delta^{18} \mathrm{O}_{\mathrm{PO} 4}$ relative to VSMOW (Vienna Standard Mean Ocean Water), while the $\delta^{13} \mathrm{C}$ and $\delta^{18} \mathrm{O}_{\mathrm{CO}}$ results from the structural carbonate analyses are shown relative to VPDB (Vienna Pee Dee Belemnite).

\section{Results}

\subsection{Major element compositions}

The remains of four mammal taxa, Daouitherium rebouli (PM65), Phosphatherium escuilliei (MNHN.F PM25), Hyracoidea indet (MNHN.F PM52), and Ocepeia grandis (PM66) were analyzed for $\mathrm{CaO}, \mathrm{P}_{2} \mathrm{O}_{5}$ and $\mathrm{F}$ content (Table 2, Figure 2). The $\mathrm{Ca} / \mathrm{P}$ ratio ranges from 1.70 to 2.02 , with the values increasing from enamel to dentine to bone. The F content varies between 0.73 and $3.95 \mathrm{wt} \%$ and a similar trend to the $\mathrm{Ca} / \mathrm{P}$ ratio can be seen, as the lower values come from the enamel, and the highest ones from the bone samples (Figure 2).

252

\subsection{Trace element compositions}


Nineteen mammal specimens, sometimes represented by several different parts (tooth enamel, dentine, and bone fragments) and/or related sediment matrix elements (coprolites, fish teeth), were involved in the trace element study. Often multiple fragments of the same individual together with dentine-enamel pairs were analyzed and considered separately. The stratigraphic origin of each mammal specimen (i.e., the layer it comes from), therefore is represented by between one and eight sub-samples (see Table 1). Each of these represents the average of 1 to 4 spot analyses (Table 2). Altogether, 67 sub-samples were analyzed, of which 32 are directly from mammal remains, while the rests are from sediment matrix elements related to the mammals. Prior study indicates that samples from the same layers yielded a similar REE distribution (Kocsis et al., 2016), and hence unique mammal fossils (e.g., types specimens) not available for sampling can be represented by geochemical data analyzed from the matrix elements in the sediments attached to these rare fossils.

The trace element concentration data and ratios are listed in Supplementary Material Table-3, and selected ones are plotted in Figures 3-5. A range of elements, such as Sr, Zn, Ba, totREE and $U$, are compared in the boxplots (Figure 3). Sr is especially enriched in the shark tooth enameloid (average $>2035$ ppm), while other types of remains hardly reach 1000 ppm. On average, the zinc concentration is somewhat higher in the enamel and enameloid, while barium is more enriched in the terrestrial remains. Variations of the early diagenetic rare earth elements (REE) and $U$ concentrations within the samples are similar to data already reported from the Ouled Abdoun Basin (Kocsis et al., 2016). For example, the denser enamel/enameloid generally yielded lower concentrations compared to dentine, bones or coprolites. Importantly, all the investigated specimens, the mammals and the marine matrix elements, show very similar REE patterns with a negative Ce-anomaly and heavy REE enrichment. The Ce-anomaly and the Pr-anomaly can be quantified as $\mathrm{Ce} / \mathrm{Ce}{ }^{*}=2 \mathrm{Ce}_{\mathrm{N}} /$ $\left(\mathrm{La}_{\mathrm{N}}+\operatorname{Pr}_{N}\right)$ and $\operatorname{Pr} / \mathrm{Pr}^{*}=2 \operatorname{Pr}_{N} /\left(\mathrm{Ce}_{\mathrm{N}}+\mathrm{Nd}_{N}\right)$, where $\mathrm{N}$ denotes the Post-Archean Australian Shale (PAAS) normalized value (McLennan, 1989). These parameters, however reveal subtle variations among the samples, as they link to stratigraphic origin rather than taxon affiliation (Figures 4-6).

\subsection{Strontium isotope ratios $\left({ }^{87} \mathrm{Sr} /{ }^{86} \mathrm{Sr}\right)$}

Four mammal specimens from different ages were chosen and altogether nine separated analyses were carried out: four enamel, three dentine and two bones (Table 2, Figure 7). 
286 The ${ }^{87} \mathrm{Sr} /{ }^{86} \mathrm{Sr}$ ratios vary between 0.707856 and 0.708182 , and a clear decreasing trend from

287

288

289

290

291

292

293

294

295

296

297

298

299

300

301

302

303

304

305

306

307

308

309

310

311

312

313

314

315

316 enamel through dentine to bones is observed. In addition, twenty-four shark tooth enameloids - 16 from the Ouled Abdoun Basin and 8 from the nearby Ganntour Basin - were measured for ${ }^{87} \mathrm{Sr} /{ }^{86} \mathrm{Sr}$ ratios, and yielded a range from 0.707714 to 0.707920 (Supplementary Material Table-5). The data are shown in Figure 7, together with a comparison to the global strontium evolution curve for the open ocean (see McArthur et al., 2020).

4.4. Stable isotope analyses $\left(\delta^{18} \mathrm{O}_{\mathrm{PO} 4}, \delta^{13} \mathrm{C}, \delta^{18} \mathrm{O}_{\mathrm{cO} 3}\right)$

Ten mammal specimens from five taxa (D. rebouli, Hyracoidea indet., P. escuilliei, $O$. grandis, E. azzouzorum; Table 2) were analysed for phosphate oxygen isotopic composition, chiefly in the tooth enamel, but a few dentine and bone samples were analysed as well. No systematic variation was observed among these materials. The $\delta^{18} \mathrm{O}_{\mathrm{PO} 4}$ data vary between 18.0 and $22.6 \%$ and the overall average value is $19.8 \pm 1.1 \%$ o $(n=19)$. Individual mean values and taxon averages are shown in Table 2, while the taxon-related variation is plotted in Figure 8. One of the Daouitherium rebouli specimens (MNHN.F PM3) yielded the highest $\delta^{18} \mathrm{O}_{\mathrm{PO} 4}$ value $(22.3 \pm 0.4 \%$ o, $n=2)$, while the other specimens (PM65, ML 20269987) of this species vary between 18.6 and $21.2 \%$. Only eight samples were analyzed for isotopic composition in the structural carbonate in the bioapatite $\left(\delta^{13} \mathrm{C}, \delta^{18} \mathrm{O}_{\mathrm{cO} 3}\right)$, belonging to four taxa. The $\delta^{13} \mathrm{C}$ derived enamel $(\mathrm{n}=5)$ ranged between -7.1 and $-8.6 \%$, while a dentine and two bone samples yielded higher values of $-6.3,-4.6$, and $-3.9 \%$, respectively (Table 2 , Figure 8). The values of $\delta^{18} \mathrm{O}_{\mathrm{CO} 3}$ ranged between -3.7 and $-5.1 \%$ for the enamel, whereas the dentine and the two bones yielded somewhat lower values of $-5.6,-5.6$, and $-5.1 \%$, respectively (Table 2 ).

\section{Discussion}

\subsection{Terrestrial, marine, and diagenetic signals}

Hard tissues (i.e., bones, teeth) of terrestrial and marine animals record the chemical and isotopic signatures of their respective environments, hence when these remains are fossilized the ancient ecological conditions can be traced in the case of no alteration (e.g., Tütken et al., 2006; Kocsis et al., 2007; Domingo et al., 2009; Reynard and Balter, 2014; 
Akhtar et al., 2020). Generally, freshwater (e.g., terrestrial drinking sources) has a lower F and $\mathrm{Sr}$ content than seawater, while $\mathrm{Ba}$ is instead expected to be higher in rivers and lakes (White 1998; Bruland and Lohan 2003; Gaillardet et al. 2003). Therefore, these elements can help tracing in-vivo preserved environmental signals, and can give information on alteration during fossilization. Moreover, the taphonomic relations of mixed assemblages, such as the one studied here, can be further investigated (e.g., Trueman et al., 2003; Tütken et al., 2008).

In this study, the low $\mathrm{F}$ and high Ba content, but also the low $\mathrm{Ca} / \mathrm{P}$ and high ${ }^{87} \mathrm{Sr} /{ }^{86} \mathrm{Sr}$ ratios in the mammal tooth enamel, indicate at least partially preserved in-vivo values reflecting a continental source and origin. The higher F and lower Ba concentrations, and Srisotope ratios in the mammal dentine and bone that are closer to marine values, are best explained by diagenesis in a seawater-dominated pore fluid (Figures 2-3). The burial condition is also reflected by the chemistry of the marine coprolites (Figure 2), which phosphatized within the sediments (Cosmidis et al., 2013), and yielded similar compositions to those of the mammal bones and dentine. Therefore, the $\mathrm{Ca} / \mathrm{P}$ ratio and $\mathrm{F}$ of these mammal remains were altered in a marine depositional setting. The latter materials have a higher susceptibility to interaction and exchange with the depositional fluid due to their lower crystallinity and density, and originally higher porosity and organic content when compared to the enamel. The higher concentrations of REE and $U$, and possibly the higher $\delta^{13} \mathrm{C}$ and lower $\delta^{18} \mathrm{O}_{\mathrm{CO}}$ values, in the dentine and bone are also the result of the postulated structural differences and related diagenesis in a marine pore-fluid (Figure $3 \& 8$, Table 2).

As an in-vivo marine environmental end-member, shark tooth enameloid is the best suited material, as it is indicated by the following geochemical data: (1) a high F content, (2) low $\mathrm{Ca} / \mathrm{P}$ ratios, (3) a high $\mathrm{Sr}$ concentration, and (4) very similar ${ }^{87} \mathrm{Sr} /{ }^{86} \mathrm{Sr}$ ratios to the open seawater of the time (McArthur et al., 2020; see chapter 5.3), and partly also (5) oxicseawater related REE patterns (Figure 4; Kocsis et al., 2016) (Figure 2).

Based on the above observations, enamel/enameloid geochemical values should be used in any ecological and in-vivo interpretations. In this sense, the somewhat higher concentrations of $\mathrm{Zn}$ in both the mammal enamel and shark tooth enameloid call for further explanation, as these values may link to a common in-vivo origin. $\mathrm{Zn}$ has been connected to enzymes (e.g., kallikrein - KLK4) that play an important role in mammal tooth enamel 
as to make the enamel harder (e.g., Simmer et al., 2009; Goetttig et al., 2010). A high Zn concentration has been detected in modern shark enameloid and a similar enzymatic process has been proposed (Kocsis et al., 2015). Therefore, the observed relatively higher $\mathrm{Zn}$ concentration in our enamel/enameloid may partly relate to the process of enamel mineralization during amelogenesis. For other in-vivo interpretations based on the stable isotope and strontium isotope ratios, see Sections 5.3 and 5.4.

\subsection{REE element taphonomy and stratigraphy}

The rare earth element content of fossil bioapatite is predominantly of early diagenetic origin and can reflect the burial fluid's REE composition (e.g., Elderfield and Pagett, 1986; Trueman and Tuross, 2002). This signature of fluid composition is frequently used to address taphonomic questions related to fossil vertebrates (e.g., Staron et al., 2001; Trueman et al., 2003; MacFadden et al., 2007; Tütken et al., 2008; Botfalvai et al., 2021) or to assess palaeoenvironmental conditions (e.g., Picard et al., 2002; Shield and Webb, 2004; Kocsis et al., 2007, 2009; Žigaitė et al., 2016, 2020). From the Ouled Abdoun and Ganntour basins in Morocco, Kocsis et al. (2016) tested over 200 bioapatite specimens, and this database has been extended here (Supplementary Material Table-1). Based on the REE concentrations, their variations along the phosphate series, and their variations within the specimens, any late diagenetic overprint or fractionation along the REE series is ruled out (e.g., Kocsis et al., 2016). Therefore, the REE patterns we have obtained, and the related elemental ratios, can confidently be linked to the depositional environment.

As was the case in the prior study, the REE content of the fossils analyzed here increases from enamel/enameloid to coprolite, dentine, and bone, which, as mentioned earlier, reflects original structural and compositional (i.e., organic content) differences among these materials. However, a very important fact is that all the samples (in this study and in Kocsis et al. 2016), yielded similar REE distributions, which mimic oxic seawater patterns (i.e., a negative Ce-anomaly and HREE enrichment) regardless of the material and taxa involved (Figure 4). This further supports the conjecture that the terrestrial mammal remains were fossilized within a marine depositional setting together with the marine fossils, and that they gained their REE content from seawater dominated pore fluids. An additional implication is that the mammal carcasses were most likely directly transported into the marine realm, without any previous terrestrial depositional site in the hinterland. This is 
compatible with the hypothesis that the terrestrial mammals were drained as floated bodies from the nearby hinterland by local rivers in the Ouled Abdoun phosphate basin, shortly after their deaths (Gheerbrant et al., 2003).

Despite the very similar REE patterns, the samples do vary in their $\mathrm{Ce} / \mathrm{Ce}{ }^{*}$ and $\mathrm{Pr} / \mathrm{Pr}$ * ratios, which together express the degree of Ce-anomaly (Figure 4) (Bau and Dulski, 1996). The variations in the ratios are time related, meaning that samples from the same bed cluster around similar values. Therefore the REE distribution of any remains from the sediment matrix, such as coprolites, pellets or small teeth, attached or embedded with the mammal fossils, represents these rare fossils with no bias (see Table 1).

The few mammal samples and/or their sediment matrix whose stratigraphic origins were previously known perfectly match the reference $\mathrm{Ce} / \mathrm{Ce}$ * curve established by Kocsis et al. (2016) (Figure 5). Moreover, taxa with presumably Paleocene (e.g., Ocepeiidae spp., Abdounodus, Eritherium) or Eocene (e.g., Phosphatherium, Daouitherium, Stylolophus spp.) ages fit in the corresponding data cluster (Figure 4).

The background $\mathrm{Ce} / \mathrm{Ce}$ * dataset for the Ouled Abdoun Basin allows for comparison of the mammal-derived data with their possible stratigraphic positions (Figures 4-6). The sedimentary section was divided into ten chemostratigraphic horizons based on the $\mathrm{Ce} / \mathrm{Ce}$ * variation and major sedimentological units including the three bone-beds (Horizons 3, 5, and 7), where mammal remains presumably were found. The variance and mean of the $\mathrm{Ce} / \mathrm{Ce}$ * values for the consecutive layers were compared using the $\mathrm{F}$ and Student's-t tests respectively (Supplementary Material Table-6), and these yielded significant differences (Student's t-test $p<0.05$ ) with the exceptions of the top of Bed-IIb (Horizon 8) and the Eritherium bone bed (Horizon 7) $(p=0.604)$. Then, in order to trace the possible stratigraphic origin of the mammals, each mammal data-group $(n>2)$ was compared to the respective horizons using one-way ANOVA (i.e., Eocene mammals to Horizons 1 - 5;

Paleocene mammals to Horizons 5 - 10), and the underlying differences in the mean $\mathrm{Ce} / \mathrm{Ce}$ * values were checked using Tukey's pairwise tests (Table 3).

\subsubsection{Paleocene taxa}

The three specimens of Eritherium azzouzorum (PM40; MNHN.F.PM42; PM100a see Table 1) found in the Eritherium bone bed fit the background $\mathrm{Ce} / \mathrm{Ce}$. data from this horizon (Horizon 7). However, they are also statistically similar to the horizons below and above. The 
$413 \mathrm{Ce} / \mathrm{Ce} *$ data of the taxa with unknown provenance revealed that their origin is restricted to the interval between the very top of Bed IIb and the base of Bed Ila, including the Eritherium bone bed (chemostratigraphic Horizons 6-8 i.e., early Thanetian-Selandian-?latest Danian age)(Figure 6, Table 3). This suggests that these mammal specimens do not come from younger Paleocene bone beds such as the big coprolite bone bed (base of Horizon 5), which was the suspected provenance of one of the $O$. grandis specimens (PM66) based on information from local collectors. Fossil collectors usually target higher accumulations of bones (i.e., the bone beds) to find unique specimens, hence the Eritherium bone bed (Horizon 7) could be the most important source of these fossils. However, our results support the hypothesis that some mammal specimens such as MNHN.F PM39 of $O$. grandis, - and solely based on its $\mathrm{Ce} / \mathrm{Ce}$ * ratio - maybe even the MNHN.F PM42 of E. azzouzorum, might be derived from layers overlying the base of Bed lla (Horizon 6) (Figure 6). Among the Ocepeiidae, the overlapping probabilities of their stratigraphic provenance indicate that the smaller 0 . daouiensis and the larger $O$. grandis were co-existing, therefore refuting the possibility that they were successive chronospecies (Table 3-4, Figure 5). For the specimens where only one $\mathrm{Ce} / \mathrm{Ce}{ }^{*}$ data point is available (Ocepeiidae? - MHNM.KHG.224 and Abdounodus hamdii - PM67), the result agree with the suggested origin in Horizons 6-8.

\subsubsection{Eocene taxa}

The Eocene taxa reveal a wider range of possible provenance beds, based on the statistical analysis (Table 3). This relates partly to the fact that the $\mathrm{Ce} / \mathrm{Ce}$ * values are increasing in the youngest beds, and so they overlap with some of the older levels, while the latest Paleocene beds (top Bed Ila - Horizon 5) show very similar values to those of the early Ypresian beds (Figure 5). An exception is Horizon 4, with few specimens (the very base of intercalary II/I), which clearly does not match any of the taxa due to its high $\mathrm{Ce} / \mathrm{Ce}$ * values, and which are similar to the older Paleocene data series. This small spike in the $\mathrm{Ce} / \mathrm{Ce}$ values may reflect reworked older specimens from Bed Ila, as has been recognized also by Gheerbrant et al. (2003), and/or a very brief episode of less oxic, somewhat confined conditions (probably after the PETM event) (Kocsis et al., 2016).

On the other hand, most of the taxa show significant undifferentiated similarities to the whole range of chemostratigraphic Horizons 1, 3, and 5, i.e. upper Thanetian-Ypresian 
define the exact provenance of the mammal taxa in these three horizons, so additional information from the sediment matrix and related selachian fauna (i.e., shark and ray) are needed for further stratigraphic assignment.

The origin of the few Phosphatherium escuilliei specimens (MNHN.F PM14 and MNHN.F PM17) is known for certain to be the Otodus obliquus bone bed in the intercalary phosphate Beds II/I (i.e., base Horizon 3) (Table-1, Gheerbrant et al., 2005), but no trace element analyses were carried out on these specimens. However, the specimens of this species with unknown provenance (MNHN.F PM25, OCP DEK/GE336) yielded $\mathrm{Ce} / \mathrm{Ce}$ * data fitting an origin in Horizon 3, which includes the Otodus obliquus bone bed (Figure 6).

The sediment matrix and the related selachian remains assigned the Stylolophus minor (OCP DEK/GE 668) specimen to the Otodus obliquus bone bed, a conclusion which is further confirmed by its $\mathrm{Ce} / \mathrm{Ce}^{*}$ values (Figure 5 ). Selachian taxa found in the matrix of the other specimen of S. minor (MNHN.F PM30) are also compatible with Horizon 3 (see Supplementary Material Table-7). The $\mathrm{Ce} / \mathrm{Ce}$ * data for the other specimens analyzed (MNHN.F PM30 \& OCP DEK/GE 667) would also match an origin in Horizon 3 (early Ypresian) (Figure 6).

For these two species ( $P$. escuilliei and S. minor), however, the general similarity in the $\mathrm{Ce} / \mathrm{Ce}$ * values to the latest Paleocene beds (Horizon 5: top Bed lla including the big coprolite bone bed) raise the possibility that some of these specimens may have belonged to the older Horizon 5. Thus, we cannot exclude that these species have crossed the PETM boundary. It must be mentioned that the provenance of $P$. escuilliei and $S$. minor from Horizon 1 (Table 3 ) is completely rejected here, due to the lack of strong similarities with the thick succession of Horizon 2, which stratigraphically follows Horizon 3 (Figure 5).

Stylolophus major (MNHN.F PM53) has the highest probability of occurrence in the youngest Horizon 1 (the sillons beds - Table 3, Figure 6). If it is correct, it would be the stratigraphically youngest mammal recovered in the Ouled Abdoun phosphate series. A stratigraphic origin of S. major from the sillons beds is further supported by its larger size and its more derived morphology with respect to $S$. minor, and also by the chert content and the selachian assemblage found in its matrix (Gheerbrant et al., 2018, 2020). In fact, this species yielded very different $\mathrm{Ce} / \mathrm{Ce}{ }^{*}$ and $\mathrm{Pr} / \mathrm{Pr}$ * ratios from the rest of the mammals (see Figure 4d), and when Tukey's pairwise comparison is applied to all these younger taxa it reveals that $S$. major is significantly different from the rest of the remains $(p<0.05$, Table 4$)$, 
477 which further supports its younger origin in the phosphate series (i.e., Horizon 1 - late 478 Middle Ypresian).

479 For Daouitherium rebouli, the matrix data and related fauna suggest an origin in Bed 0 or 480 Bed 0' (Horizon 2) (see Supplementary Material Table-7). Generally, our Ce/Ce* data 481 support this scenario, although Horizons 1 and 3 yielded a higher probability match. 482 Moreover, these specimens do not differ in their $\mathrm{Ce} / \mathrm{Ce}{ }^{*}$ values from those of $P$. escuilliei and S. minor (Table 4). The $\mathrm{Ce} / \mathrm{Ce}^{*}$ data match Horizon 5 (Paleocene), but the attached matrix-type and related selachian fauna preclude this scenario (see Table 3). Daouitherium is the largest proboscidean from the Ouled Abdoun Basin and most probably evolved somewhat later than Phosphatherium, so the younger age might be possible too (Gheerbrant et al., 2002). Here we propose an origin in the interval from the top Horizon 3 to Horizon 2 (middle Ypresian) (see the grey shaded area in Figure 5).

The difficulties in pinpointing more precise stratigraphic provenances based on only the $\mathrm{Ce} / \mathrm{Ce}$ * data is clear from the above example, and the limitations of the method are further highlighted by the Hyracoidea specimen (MNHN.F PM52), for which no additional matrix related information is available. The similar probability pattern to the $D$. rebouli specimens (Table 3) may suggest a similar origin; while significant differences from the holotype of $S$. major (Table 4) would argue against a provenance in Horizon 1. Therefore, we propose here a possible origin for the Hyracoidea from the top of Horizon 3 to Horizon 2 (middle Ypresian).

To sum up, in general the chemostratigraphic approach supports the previous assumptions made about the provenances of the mammal taxa investigated here, but it has also shed light on certain peculiarities such as (1) the Ocepeiidae species, in particular $O$. daouiensis and $O$. grandis, coexisted in the Ouled Abdoun phosphate series for an undetermined period from the latest Danian to the early Thanetian; (2) the Ypresian species P. escuilliei and S. minor might have already evolved in the latest Paleocene; (3) Stylolophus major is the youngest and only known mammal taxon derived from the highest phosphorite sillons beds (late Middle Ypresian). Based on the $\mathrm{Ce} / \mathrm{Ce}$ data and additional matrix and biostratigraphic (i.e., selachian fauna) information, the most probable stratigraphic origin of the mammal specimens are marked by the grey areas in Figure 6. 


\subsection{Strontium isotope ratios in terrestrial and marine fossils}

The $\mathrm{Sr}$ that is biologically available in a terrestrial environment is affected by the local geology, and it is incorporated into the skeletal tissues via ingestion without fractionation along the food chain (e.g., Blum et al., 2000). Therefore, the strontium isotope ratios $\left({ }^{87} \mathrm{Sr} /{ }^{86} \mathrm{Sr}\right)$ of fossil terrestrial mammals are often used to trace migration patterns (e.g., Hoppe et al., 1999; Tütken et al., 2006; Arppe et al., 2009). On the other hand, in the open marine realm the seawater has a constant ${ }^{87} \mathrm{Sr} /{ }^{86} \mathrm{Sr}$ ratio due to the long residence time of Sr. However, on longer timescale the ratio does vary, and this variation is the basis of strontium isotope stratigraphy (e.g., McArthur et al. 2020). Dating marine rocks with wellpreserved fish remains is one widely used approach (e.g., Ingram 1995; Kocsis et al., 2013; Harrell et al., 2016), while in the case of mixed terrestrial and marine assemblages, taphonomy of the remains can give further information.

Our ${ }^{87} \mathrm{Sr} /{ }^{86} \mathrm{Sr}$ analyses from the Ouled Abdoun basin yielded differences between the continental and marine taxa, with the mammal fossils in general having higher ratios (Figure 7a). The highest ratios come from mammal enamel that represents possibly unaltered terrestrially-derived and ingested Sr (i.e., in-vivo), which reflects the hinterland geology of the time. The ${ }^{87} \mathrm{Sr} /{ }^{86} \mathrm{Sr}$ ratios decrease through dentine to the bone samples, which approaches the values of the open ocean (Figure 7a). This decreasing trend within the different types of mammal remains clearly indicates diagenesis in a marine depositional environment, and as mentioned earlier this has an important taphonomic message. The remains were originally deposited in a marine setting and they are not reworked from previous deposits.

On the other hand, the data derived from the shark tooth enameloid more or less follow the global open ocean Sr-evolution curve. This is most noticeable for the latest Paleocene and Eocene where the Sr-isotope ages agree with other chemostratigraphic data (Yans et al., 2014; Kocsis et al., 2014a). However, the rest of the Paleocene and part of the Cretaceous samples yielded ${ }^{87} \mathrm{Sr} /{ }^{86} \mathrm{Sr}$ ratios that cannot fit the global $\mathrm{Sr}$-isotope curve because their values are too high (Figure 7). The most plausible interpretation is that these samples were altered during early diagenesis. A high ${ }^{87} \mathrm{Sr} /{ }^{86} \mathrm{Sr}$ ratio could have derived from a terrestrial source, as attested by the mammal enamel's high ${ }^{87} \mathrm{Sr} /{ }^{86} \mathrm{Sr}$ values. However, there is no evidence of strong continental input in the sedimentary record of the phosphates series, which corresponds mostly to non-clastic deposits of biogenic origin (i.e., 
marine bioproductite see Lucas and Prevôt-Lucas, 1995). The continental influence is marked there only by occasional rare terrestrial fossils in the phosphate levels. The

543 terrestrial sediment input in the Moroccan phosphate basins was low, due maybe to the flat topography in the hinterland (low hydrodynamism and erosion) and perhaps also to the filtering role of coastal mangroves (e.g., Fechner, 1988). However, the river water and/or sub-terrain water draining from the hinterland towards the basin may have had some effects, at least in the transportation of the floating bodies/carcasses of the Ouled Abdoun mammals (Gheerbrant et al., 2003).

The REE element patterns, however, were still compatible with oxic seawater (Figure 4). Though the $\mathrm{Ce} / \mathrm{Ce}$ * ratios are somewhat higher here than in the younger samples (Figure 5), the stratigraphic changes in these values were interpreted as a reflection of the enhanced opening of the Atlantic Ocean and hence a better connection with the global oceanic circulation (Kocsis et al., 2016). In this sense the ${ }^{87} \mathrm{Sr} /{ }^{86} \mathrm{Sr}$ data of the Cretaceous and older Paleocene samples could indicate somewhat more restricted conditions in which seawater was slightly locally controlled. First-order sea-level changes during the late Cretaceous and early Paleogene indicate global regression (e.g., Hardenbol et al., 1998; Snedden and Liu, 2010; van der Meer et al., 2017), which could support the semi-confined situation in the Moroccan phosphate basins. Interestingly, the ${ }^{87} \mathrm{Sr} /{ }^{86} \mathrm{Sr}$ data reported from foraminifera from the South Atlantic (Walvis Ridge) also yielded rather higher ratios than the global ocean Sr-isotope curve during this part of the Paleocene (Hodell et al., 2007). Even if some samples were clearly affected by diagenesis the lowest Sr-isotopic ratios have a perfect fit with McArthur's curve between 52 and $58 \mathrm{Ma}$ (Figure 7b), but the older samples are above the curve at the Walvis Ridge as well. This might hint at a common cause altering the Srbudget and its mixing in the Central and South Atlantic, which may have been related to the formation of wider scales of global oceanic circulation. Nevertheless, better suited samples covering larger regions are needed to seriously assess this scenario.

\subsection{Mammal ecology based on stable isotope chemistry}

The oxygen and carbon isotopic compositions of fossil mammal teeth are often used for palaeoecological and palaeoenvironmental reconstructions (e.g., Ayliffe et al., 1994; Kohn and Cerling, 2002; Amiot et al., 2004), even for extinct taxa of the Paleocene and Eocene for which the physiology of the animals is more difficult to assess (e.g., Liu et al., 2008; Secord 
et al., 2008; Kocsis et al., 2014b; Mahboubi et al., 2014; Tütken, 2014). Nevertheless, based on the tooth morphology the mammals from the Ouled Abdoun Basin investigated here were all herbivores (Ypresian proboscideans are especially folivorous specialists). Their body fluid $\delta^{18} \mathrm{O}$ depends on the ingested water, which mainly came from drinking sources and/or dietary plant water, while their $\delta^{13} \mathrm{C}$ was entirely driven by their diet and can be related to the palaeoflora (e.g., Kohn and Cerling, 2002). The growth of teeth and bones record these ecological parameters, and can be used to gain information about the past environment. The teeth and bones are composed of bioapatite with a simplified formula of $\mathrm{Ca}_{5}\left(\mathrm{PO}_{4}\right.$, $\left.\mathrm{CO}_{3}\right)_{3}\left(\mathrm{OH}, \mathrm{CO}_{3}\right)$. From the oxygen bearing ions, the phosphate ion dominates the apatite structure and is considered to be the most resistant to diagenesis due to the strong P-O bond. Therefore, the phosphate oxygen isotopic composition $\left(\delta^{18} \mathrm{O}_{\mathrm{PO} 4}\right)$ can provide the most reliable ecological information. To further evaluate possible alterations, enamel, dentin and bone can be analyzed separately and compared, with the enamel considered to be less prone to diagenetic alteration (e.g., Zazzo et al., 2004). The $\delta^{18} \mathrm{O}_{\mathrm{PO} 4}$ data from the Moroccan mammals do not show consistent variations across these materials, but the $\delta^{13} \mathrm{C}$ of $O$. grandis and P. escuilliei clearly point towards higher values in the less dense material of bone and dentine (Figure 8). This can be interpreted as meaning that the $\delta^{18} \mathrm{O}_{\mathrm{PO}}$ data are more robust across the various materials; however the isotope values from the structural carbonate underwent partial interaction and exchange with the marine pore fluid in the depositional environment. For this reason, only the enamel data are taken into account when the ecology of these ancient mammals is discussed, even for the $\delta^{18} \mathrm{O}_{\mathrm{PO} 4}$ results.

The overall average $\delta^{18} \mathrm{O}_{\mathrm{PO} 4}$ value for the enamel is $20.0 \pm 1.3 \%(n=12)$, and no obvious species-specific variations occur. The largest variation is between two specimens of Daouitherium rebouli (MNHN.F PM3 and PM65), with a nearly $3 \%$ difference in their enamel values (Figure 8). The relationship between mammal $\delta^{18} \mathrm{O}_{\mathrm{PO} 4}$ and the local meteoric water (i.e., consumed water) can be taxon specific and dependent also on the relative humidity (e.g., Kohn, 1996; Ayliffe et al., 1994; Kohn and Cerling, 2002). This can be complicated further by the migration of animals, seasonal variations, and/or locally available water sources that are different from the local meteoric water. Moreover, the physiology of the investigated taxa is hard to assess, and for these reasons Amiot et al. (2004)'s globally 
604

605

606

607

608

609

610

611

612

613

614

615

616

617

618

619

620

621

622

623

624

625

626

627

628

629

630

631

632

633

634

is used here, with the assumption that the ancient mammals' body fluids were affected by the local meteoric fluid (i.e., drinking water or plant water). This would yield an average of $4.2 \pm 1.3 \%$ o $(n=12)$ local meteoric water isotopic composition, which in turn can be linked to a mean annual temperature of $20.4 \pm 3.0^{\circ} \mathrm{C}(n=12)$ (see Amiot et al., 2004) for the late Paleocene and early Eocene (Figure 8 ). This is about $2-3^{\circ} \mathrm{C}$ degrees higher than today's MAT for the coastal area of Morocco (e.g., Agadir-Casablanca, see climate-data.org). Considering the palaeolatitudinal temperature gradient for a greenhouse climate regime (Amiot et al., 2004) and the fact that the studied sites were not much further south $\left(\sim 22^{\circ}-24^{\circ} \mathrm{N}\right.$, see van Hinsbergen et al., 2015) than today, the absolute MAT result we obtained seems reasonable. Nevertheless, the higher isotopic composition in the bioapatite indicates a higher isotopic composition in the ingested water, which in turn reflects a higher MAT (Figure 8). The high $\delta^{18} \mathrm{O}_{\mathrm{PO} 4}$ values for one of the D. rebouli (MNHN.F PM3) and Hyracoidea (MNHN.F PM52) teeth may reflect the effects of the Early Eocene Climatic Optimum (EECO), with arelated global temperature rise and/or enhanced dryer periods (i.e., more evaporation of the drinking sources). However, only a few samples were analyzed and the high $\delta^{18} \mathrm{O}_{\mathrm{PO} 4}$ values and related temperature calculations might be biased by the migration of the animals or strong evaporation of the local drinking source. Geochemical analysis of the sediments and the marine fossils had also detected the EECO event in the phosphorite series (Yans et al., 2014; Kocsis et al., 2014). Moreover, the stratigraphic average MATs reveals a rise of about $5^{\circ} \mathrm{C}$ degree from the early Ypresian to mid-Ypresian (Figure 8), which agrees well with the peak of the EECO and related $\triangle M A T$ estimates (e.g., Hyland et al. 2016). If these analyses indeed reflect the EECO, then the proposed stratigraphic origin of these taxa (D. rebouli \& Hyracoidea) in Horizons 3 (upper part) and 2 is further confirmed (see section 4.2 and Figure 6).

The average enamel $\delta^{13} \mathrm{C}$ value is $-7.9 \pm 0.8 \%$ o $(n=5)$, which can be translated to a consumed plant isotopic composition of $-22 \pm 0.8 \%$ (e.g., Kohn and Cerling, 2002; Figure 8). This mean value is at the very high end of a C3 palaeoflora, and because the C4 photosynthetic pathway was not yet widespread (i.e., high $\delta^{13} C_{\text {plant }}$ ), this suggests a very dry Thanetian-middle Ypresian local continental palaeoecosystem with mean annual precipitation well below 500 mm (Kohn, 2010). A dry arid early Eocene climate was also suggested by palynology and palaeobotanic finds in the Moroccan south Atlas, which 
indicated mangrove and marsh vegetation along the palaeo-coast, together with a fairly dry and scarcely vegetated hinterland (Mohr, 1986; Mohr and Fechner, 1986; Fechner, 1988). Mangrove vegetation along the coast line is also predicted by models (Descombes et al., 2018; Couvreur et al., 2021). The presence of early diagenetic dolomite and gypsum in some of these deposits were also interpreted as a consequence of an arid climate during the Ypresian, and only a low amount of seasonal precipitation was proposed (e.g., Mohr, 1986; Fechner, 1988). In addition, the rarity of detritic (clastic) material in the phosphate basins (Lucas and Prevôt-Lucas, 1995), and the high quantity of palygorskite clay mineral in the Paleogene deposits in the Atlas (Daoudi, 2004; Knidiri et al., 2014) and offshore Morocco (e.g., Chamley et al., 1980), would further suggest a dry semi-arid late Paleocene - Ypresian climate in the region. By contrast, Herbig and Gregor (1990) have advocated a tropical humid climate based on the discovery of mangrove macro-plant remains of Nypa palms from Thanetian-Ypresian levels in the Ouarzazate Basin, based on a re-evaluation of early available data.

In the view of the mammal enamel $\delta^{13} \mathrm{C}$ values from the Ouled Abdoun Basin, the ingested plants must have lived in water-stressed, and maybe also salinity-stressed (i.e., mangrove vegetation, e.g., Wei et al., 2008) environment, supporting the hypothesis of arid late Paleocene - Ypresian climatic conditions in the region. The minimal variation in the $\delta^{13} \mathrm{C}$ values through time could reflect a steady dry ecosystem along the Moroccan coastline during the Paleocene-Eocene. Still, the EECO warm period may have stressed the palaeoflora further, and even somewhat higher values of $\delta^{13} \mathrm{C}$ may be expected (e.g., even more water stress, Farquhar et al., 1989). However, this may have been compensated by a higher relative humidity and / or higher atmospheric $\mathrm{pCO}_{2}$ during the EECO (Pearson and Palmer, 2000; Schubert and Jahren, 2002). The EECO warming is likely also to have driven an evolution to increased size the Ouled Abdoun mammals (e.g., Yans et al., 2014). The embrithopods lineage S. minor-S. major (Gheerbrant et al., 2020) records a significant increase in size during the early-middle Ypresian. Similar size changes are observed between Phosphatherium and Daouitherium, however with much less stratigraphic difference between these taxa as inferred here (Figure 6).

\section{Conclusions}


The rare but diverse terrestrial mammal fossils from the Ouled Abdoun phosphorite are proven to have a similar diagenetic history to that of the marine fossils. This is reflected by a similar REE distribution and stratigraphy matched $\mathrm{Ce} / \mathrm{Ce}$ * and $\mathrm{Pr} / \mathrm{Pr} *$ ratios. The $\mathrm{Ce} / \mathrm{Ce}$ * variation along the phosphate series either confirmed previous known origins or helped to estimate the stratigraphic provenance of the Ouled Abdoun mammal specimens whose origin was unknown. Exchanges with marine pore fluid affected the enamel, dentine, and bone differently, with the enamel being the most robust to alteration, and hence the best to use for investigation of the palaeoenvironment of the African Paleogene mammals from the Ouled Abdoun sites.

This study has identified ten chemostratigraphic horizons in the Maastrichtian-Ypresian phosphates series of the Ouled Abdoun Basin. It confirms most of the previously proposed age determinations for the mammals found in the Ouled Abdoun Basin, but with some corrections and additions. One new conclusion is that all the Paleocene mammal material studied here ranges from the Selandian to the lower Thanetian (uppermost Bed Ilb to the base of Bed Ila). In particular, O. grandis does not come from the upper part of Bed lla (late Thanetian) but is actually a coexisting lineage with $O$. daouiensis, which highlights the littleknown radiation of the stem paenungulates. The study suggests that some mammal species might have a wider stratigraphical extension than previously known, including across the PETM. However, as the Ouled Abdoun mammal material remains scarce, it is unknown if this relates to the presence of undetermined chronospecies or to the succession of intraspecific diachronic populations. Chemostratigraphic results indicate that the embrithopod S. major likely comes from the uppermost phosphates levels (late Middle Ypresian) of the Ouled Abdoun series, and is the youngest Paleogene mammal known in the Ouled Abdoun Basin.

While the mammal enamel yielded the highest ${ }^{87} \mathrm{Sr} /{ }^{86} \mathrm{Sr}$ ratios, indicating the composition of the hinterland rocks (a terrestrial Sr-source), the ratios for the shark tooth enameloid from the latest Paleocene to early Eocene are compatible with the open ocean Sr isotope ratios of the time. Older marine fossils deviate from the global Sr-isotope curve, which most probably reflects alteration or may link to somewhat restricted conditions and a variable Srbudget in the African coastal basins of the Atlantic Ocean. The enamel derived oxygen and carbon isotopic compositions of the Ouled Abdoun mammal teeth point to warm and arid climatic conditions along the Atlantic palaeocoast of North Western Africa. In addition, an 

evolution of endemic African lineages of placental mammals, such as the early embrithopod Stylolophus, during the EECO event.

702

\section{Acknowledgements}

704

The research was conducted under L.K.'s Ambizione research grants (Nr. PZ00P2_126407 \& PZ00P2_145115/1 - Switzerland), but in the later phase of the project LK also received support from his URC Grant from Universiti Brunei Darussalam (UBD/PNC2/2/RG/1(325)).

The help from both funding agencies is much appreciated. This study benefited from the paleontological "Phosphapal" collaborative Agreement with the Ministère de l'Energie, des Mines, de l'Eau et de l'Environnement (MEMEE), the Office Chérifien des Phosphates (OCP SA) of Morocco, the Muséum National d'Histoire Naturelle (MNHN, Paris), and the Universities Cadi Ayyad (Marrakech, Morocco) and Chouaıb Doukkali (El Jadida, Morocco). We are most grateful to the Geological Survey of the OCP mining centre of Khouribga for help with the field work. Identification of the matrix related selachian fauna by Prof. Henri Cappetta (CNRS, Université de Montpellier II, France) is much appreciated. Constructive comments on a previous version of the manuscript by the editor Thomas Algeo, and three reviewers, Živilè Žigaitè and 2 anonymous ones, are much appreciated. We thank Malcolm R. Anderson for proofreading the updated manuscript.

\section{References}

Akhtar, A.A., Santi, M.L., Griffiths, L.M., Becker, M., Eagle, A.R., Kim, S., Kocsis, L., Rosenthal, Y., Higgins, J.A., 2020. A record of the $\delta^{44} /{ }^{40} \mathrm{Ca}$ and [Sr] of seawater over the last 100 million years from fossil elasmobranch tooth enamel. Earth and Planetary Science Letters 543, doi.org/10.1016/j.epsl.2020.116354.

Amiot, R., Lecuyer, C., Buffetaut, E., Fluteau, F., Legendre, S., Martineau, F., 2004. Latitudinal temperature gradient during the Cretaceous Upper Campanian Middle Maastrichtian: $\delta^{18} O$ record of continental vertebrates. Earth Planet. Sci. Lett. 226, 255-272. http://dx.doi.org/10.1016/j.epsl.2004.07.015.

Arambourg, C., 1952. Les vertébrés fossiles des gisements de phosphates (Maroc-Algérie-Tunisie). Notes Mémoires du Service géologique du Maroc 92, pp. 1-372.

Arppe L., Karhu J.A., Vartanyan S.L., 2009. Bioapatite ${ }^{87} \mathrm{Sr} /{ }^{86} \mathrm{Sr}$ of the last woolly mammoths - implications for the isolation of Wrangel Island. Geology 37, 347-350.

Ayliffe, L.K., Chivas, A.R., Leakey, M.G., 1994. The retention of primary oxygen isotope compositions of fossil elephant skeletal phosphate. Geochim. Cosmochim. Acta 58, 5291-5298. http://dx.doi.org/10.1016/0016-7037(94)90312-3.

Bardet, N., Gheerbrant, E., Noubhani, A., Cappetta, H., Jouve, S., Bourdon, E., Pereda Suberbiola, X., Jalil, N.-E., Vincent, P., Houssaye, A., Solé, F., El Houssaini, Kh., Adnet, S., Rage, J.-C., Lapparent de Broin, F., Sudre, J., Bouya, B., Amaghzaz, M., Meslouh, S., 2017. Les vertébrés fossiles des phosphates crétacés- 
paléogènes (72,1-47,8 Ma) du Maroc, in Zouhri, S. ed., Paléontologie des Vertébrés du Maroc: état des connaissances. Mémoire de la Société Géologique de France, v. 180, p. 351-452.

Bau, M., Dulski, P., 1996. Distribution of yttrium and rare-earth elements in the Penge and Kuruman ironformations, Transvaal Supergroup, South Africa. Precambrian Res. 79, 37-55.

Blum, J.D., Taliaferro, E.H., Weisse, M.T., Holmes, R.T., 2000. Changes in Sr/Ca, Ba/Ca and 87Sr/86Sr ratios between two forest ecosystems in the northeastern USA. Biogeochemistry 49, 87-101.

Botfalvai, G., Csiki-Sava, Z., Kocsis, L., Gáspár, A., Magyar, J., Bodor, R.E., Țabără, D., Ulyanov, A., Makádi, L., 2021. X' marks the spot! Sedimentological, geochemical and palaeontological investigations of Late Cretaceous (Maastrichtian) vertebrate fossil localities from Vălioara Valley (Densus-Ciula Formation, Hateg Basin, Romania). Cretaceous Research, 123.

Bourdon, E., Bouya, B., larochene, M. 2005. Earliest African neornithine bird: A new species of Prophaethontidae (Aves) from the Paleocene of Morocco. Journal of Vertebrate Paleontology, 25 (1), 157-170.

Bruland, K.W., Lohan, M.C., 2003. Controls of Trace Metals in Seawater. In: Holland, H.D., Turekian, K.K. (eds) Treatise on Geochemistry, vol. 6. pp 23-47.

Cappetta, H., Bardet, N., Pereda-Suberbiola, X., Adnet, S., Akkrim, D., Amalik, M., Benabdallah, A., 2014. Marine vertebrate faunas from the Maastrichtian phosphate deposits of the Benguérir area (Ganntour Basin, Morocco): biostratigraphy, palaeobiogeography and palaeoecology. Palaeogeogr. Palaeoclimatol. Palaeoecol. 409, 217-238.

climate-data.org

Chamley H., Giroud d'Argoud G., Robert C., 1980. Clay mineralogy of Cretaceous and Cenozoic sediments off the Moroccan margin, Deep Sea Drilling Project sites 415, 416. Initial Rep. Deep Sea Drilling Proj., 50, 715-721.

Cosmidis, J., Benzerara, K., Menguy, N., Arning, E., 2013. Microscopy evidence of bacterial microfossils in phosphorite crusts of the Peruvian shelf: Implications for phosphogenesis mechanisms. Chemical Geology, 359, 10-22.

Couvreur, T.L.P., Dauby, G., Blach-Overgaard, A., Deblauwe, V., Dessein, S., Droissart,V., Hardy, O.J., Harris, D.J., Janssens, S.B., Ley, A.C., Mackinder, B.A., Sonké, B., Sosef, M.S.M., Stévart, T., Svenning, J.-C., Wieringa, J.J., Faye, A., Missoup, A.D., Tolley, K.A., Nicolas, V., Ntie, S., Fluteau, F., Robin, C., Guillocheau, F., Barboni, D., Sepulchre, P., 2021. Tectonics, climate and the diversification of the tropical African terrestrial flora and fauna. Biol. Rev. 96, 16-51.

Daoudi L., 2004. Palygorskite in the uppermost Cretaceous-Eocene Rocks from Marrakech High Atlas, Morocco. Journal of African Earth Sciences, 39, 353-358.

Descombes, P., Gaboriau, T., Albouy, C., Heine, C., Leprieur, F., Pellissier, L., 2018. Linking species diversification to palaeo-environmental changes: a processbased modelling approach. Global Ecology and Biogeography 27, 233-244.

Domingo, L., Cuevas-González, J., Grimes, S.T., Hernández Fernández, M., López-Martínez, N., 2009. Multiproxy reconstruction of the paleoclimate and paleoenvironment of the Middle Miocene Somosaguas site (Madrid, Spain) using herbivore tooth enamel. Palaeogeogr. Palaeoclimatol. Palaeoecol., 272, 53-68.

El Assel, N., Kchikach, A., Durlet, C., AlFedy, N., El Hariri, K., Charroud, M., Jaffal, M., Jourani, E., Amaghzaz, M., 2013. Mise en évidence d'un Sénonien gypseux sous la série phosphatée du bassin des Ouled Abdoun: Un nouveau point de départ pour l'origine des zones dérangées dans les mines à ciel ouvert de Khouribga, Maroc. Estudios Geológicos, 69(1), 47-70. https://doi.org/10.3989/egeol.40781.168

Elderfield, H., Pagett, R., 1986. Rare earth elements in ichthyoliths: variations with redox conditions and depositional environment. Sci. Total Environ. 49, 175-197.

El Haddi, H., 2014. Les silicifications de la série phosphatée des Ouled Abdoun (Maastrichtien-Lutétien Maroc): Sédimentologie, Minéralogie, Géochimie et Contexte Génétique, [PhD Thesis]: Université Hassan II de Casablanca, Faculté des Sciences Ben M'Sik, 135 p.

Farquhar G.D., Ehleringer J.R., Hubick, K.T., 1989. Carbon isotope discrimination and photosynthesis. Ann. Rev. Plant Physiol. Plant Mol. Biol. 40, 503-537.

Fechner, G.G., 1988. Selected palynomorphs from the Lower to Middle Eocene of the south Atlas Border Zone (Morocco) and their environmental significance. Palaeogeogr. Palaeoclimatol. Palaeoecol. 65, 73-79.

Gaillardet, J., Viers, J., Dupré, B., 2003. Trace Elements in River Waters. In: Holland, H.D., Turekian, K.K. (eds) Treatise on Geochemistry, vol. 5. Pp. 225-272.

Gheerbrant, E., 2009. Paleocene emergence of elephant relatives and the rapid radiation of African ungulates. Proceedings of the National Academy of Sciences 106, 10717-10721. 
Gheerbrant, E., Sudre, J., Cappetta, H., Bignot, G., 1998. Phosphatherium escuilliei du Thanétien du bassin des Ouled Abdoun (Maroc), plus ancien proboscidien (Mammalia) d'Afrique. Geobios 30, 247-269.

Gheerbrant, E., Sudre, J., larochene, M., Moumni, A., 2001. First ascertained African "condylarth" mammals (primitive ungulates : cf. Bulbulodentata \& cf. Phenacodonta) from the Earliest Ypresian of the Ouled Abdoun Basin, Morocco. Journal of Vertebrate Paleontology 21, 107-118.

Gheerbrant, E., Sudre, J., Cappetta, H., larochène, M., Amaghzaz, M., Bouya, B., 2002. A new large mammal from the Ypresian of Morocco: Evidence of surprising diversity of early proboscideans. Acta Palaeontologica Polonica. 47 (3), 493-506.

Gheerbrant, E., Sudre, J., Cappetta, H., Mourer-Chauvire, C., Bourdon, E., larochene, M., Amaghzaz, M., Bouya, B., 2003. Les localités à mammifères des carrières de Grand Daoui, Bassin des Ouled Abdoun, Maroc, Yprésien : premier état des lieux. Bulletin de la Société Géologique de France 174, 279-293.

Gheerbrant, E., Sudre, J., Tassy, P., Amaghzaz, M., Bouya, B., larochène, M., 2005. "Nouvelles données sur Phosphatherium escuilliei (Mammalia, Proboscidea) de l'Eocene inférieur du Maroc, apports à la phylogeny of the Proboscidea et the ongulés lophodontes". Geodiversitas. 27 (2), 239-333.

Gheerbrant, E., Bouya, B., Amaghzaz, M., 2012. Dental and cranial anatomy of Eritherium azzouzorum from the Paleocene of Morocco, earliest known proboscidean mammal. Palaeontographica, A 297, 151-183.

Gheerbrant, E., Amaghzaz, M., Bouya, B., Goussard, F., Letenneur, C., 2014. Ocepeia (middle Paleocene of Morocco): the oldest skull of an afrotherian mammal. PLOS One 9, 1-30 (DOI: 10.1371/journal.pone.0089739).

Gheerbrant, E., Cappetta, H., Lapparent de Broin, F. de, Rage, J.-C., and Tabuce, R., 2017. Les faunes de vertébrés marins et terrestres du Paléogène du Bassin d'Ouarzazate, Maroc, in Zouhri, S. ed., Paléontologie des Vertébrés du Maroc: état des connaissances. Mémoire de la Société Géologique de France, v. 180, p. 485-525.

Gheerbrant, E., Schmitt, A., Kocsis, L., 2018. Early African fossils elucidate the origin of embrithopod mammals. - Current Biology 28, 1-7. - https://doi.org/10.1016/i.cub.2018.05.032

Gheerbrant, E., Khaldoune, F., Schmitt, A., Tabuce, R., 2020. Earliest embrithopod mammals (Afrotheria, Tethytheria) from the Early Eocene of Morocco: anatomy, systematics and phylogenetic significance. Journal of Mammal Evolution. https://doi.org/10.1007/s10914-020-09509-6

Goettig, P., Magdolen, V., Brandstetter, H., 2010. Natural and synthetic inhibitors of kallikrein-related peptidases (KLKs). Biochimie 92, 1546-1567.

Hardenbol, J., Thierry, J., Farley, M.B., Jacquin, T., de Graciansky, P.-C., Vail, P.R., 1998. Mesozoic and Cenozoic sequence stratigraphy of European basins. SEPM Spec. Publ. 60, 3-13.

Harrell, T.L., Pérez-Huerta, A., Phillips, G., 2016. Strontium isotope age-dating of fossil shark tooth enameloid from the Upper Cretaceous Strata of Alabama and Mississippi, USA. Cretac. Res. 62, 1-12.

Herbig, H.G., Gregor H.J., 1990. The mangrove-forming palm Nypa from the early Paleogene of southern Morocco. Paleoenvironment and paleoclimate. In: Géologie Méditerranéenne. Tome 17, numéro 2 , 1990. pp. 123-137.

Herwartz, D., Tütken, T., Münker, C., Jochum, K.P., Stoll, B., Sander, P.M., 2011. Timescales and mechanisms of REE and Hf uptake in fossil bones. Geochim. Cosmochim. Acta 75, 82-105.

Herwartz, D., Tütken, T., Jochum, K.P., Sander, P.M., 2013. Rare earth element systematics of fossil bone revealed by LA-ICPMS analysis. Geochim. Cosmochim. Acta 103, 161-183.

Hodell, D.A., Kamenov, G.D., Hathorne, E.C., Zachos, J.C., Röhl, U., Westerhold, T., 2007. Variations in the strontium isotope composition of seawater during the Paleocene and early Eocene from ODP Leg 208 (Walvis Ridge). Geochem Geophys Geosyst 8:Q09001. doi:10.1029/2007GC001607

Hoppe, K.A., Koch, P.L., Carlson, R.W., Webb, S.D., 1999. Tracking mammoths and mastodons: reconstruction of migratory behavior using strontium isotope ratios. Geology 27, 439-442.

Hyland, G.E., Sheldon, D.N., Cotton, M.J. 2017. Constraining the early Eocene climatic optimum: A terrestrial interhemispheric comparison. GSA Bulletin, 129 (1-2), 244-252.

Ingram, B.L., 1995. High-resolution dating of deep-sea clays using Sr isotopes in fossil fish teeth. Earth and Planetary Science Letters 134, 545-555.

Knidiri, A., Daoudi, L., El Ouahabi, M., Rhouta, B., Rocha, F., Fagel, N., 2014. Palaeogeographic controls on palygorskite occurrence in Maastrichtian-Palaeogene sediments of the western High Atlas and Meseta Basins (Morocco).Clay Minerals 49, 595-608.

Kocsis. L., Vennemann, T.W., Fontignie, D., 2007. Migration of sharks into freshwater systems during the Miocene and implications for Alpine paleoelevation. Geology, 35, 451-454.

Kocsis, L., Osi, A., Vennemann, T.W., Trueman, N.C., Palmer, R.M., 2009. Geochemical study of vertebrate fossils from the Upper Cretaceous (Santonian) Csehbánya formation (Hungary): evidence for a 
freshwater habitat of mosasaurs and pycnodont fish. Palaeogeogr. Palaeoclimatol. Palaeoecol. 280, 532-542.

Kocsis, L., Trueman, C.N., Palmer, M., 2010. Protracted diagenetic alteration of REE contents in fossil bioapatites: direct evidence from Lu-Hf isotope systematics. Geochim. Cosmochim. Acta 74, 60776092.

Kocsis, L., Ounis, A., Chaabani F., Salah, N.M., 2013. Paleoenvironmental conditions and strontium isotope stratigraphy in the Paleogene Gafsa Basin (Tunisia) deduced from geochemical analyses of phosphatic fossils. International Journal of Earth Sciences 102, 1111-1129.

Kocsis, L., Gheerbrant, E., Mouflih, M., Cappetta, H., Yans, J., Amaghzaz, M., 2014a. Comprehensive stable isotope investigation of marine biogenic apatite from the late Cretaceous-early Eocene phosphate beds of Morocco. - Palaeogeography, Palaeoclimatology, Palaeoecology, 394, 74-88.

Kocsis, L., Ozsvart, P., Becker, D., Ziegler, R., Scherler, L., Codrea, V., 2014b. Orogeny forced terrestrial climate variation during the late Eocene-early Oligocene in Europe. Geology 42, 727-730. http://dx.doi.org/10.1130/g35673.1.

Kocsis, L., Vennemann, T., Ulianov, A., Brunnschweiler, J.M., 2015. Tracing bull shark (Carcharhinus leucas) freshwater habitats in Fiji by chemical and isotopic compositions of their teeth. Environ. Biol. Fish 98 (6), 1609-1622.

Kocsis, L., Gheerbrant, E., Mouflih, M., Cappetta, H., Ulianov, A., Chiaradia, M., Bardet, N., 2016. Gradual changes in upwelled seawater conditions (redox, $\mathrm{pH}$ ) from the late Cretaceous through early Paleogene at the northwest coast of Africa: Negative Ce anomaly trend recorded in fossil bio-apatite. .Chemical Geology 421, 44-54.

Kohn, M.J., 1996. Predicting animal delta O-18: Accounting for diet and physiological adaptation. Geochim. Cosmochim. Acta 60, 4811-4829. http://dx.doi.org/10.1016/s0016-7037(96)00240-2.

Kohn, M.J., 2010. Carbon isotope compositions of terrestrial C3 plants as indicators of (paleo) ecology and (paleo)climate. National Academy of Sciences Proceedings, v. 107, p. 19691-19695, doi:10.1073/pnas.1004933107.

Kohn, M.J., Cerling, T.E., 2002, Stable isotopes of biological apatite, in Kohn, M.L., et al., eds., Phosphates: Geochemical, geobiological and materials importance: Mineralogical Society of America Reviews in Mineralogy Volume 48, p. 455-488.

Kowal-Linka, M., Jochum, K.P., Surmik, D., 2014. LA-ICP-MS analysis of rare earth elements in marine reptile bones from the Middle Triassic bonebed (Upper Silesia, S Poland): impact of long-lasting diagenesis, and factors controlling the uptake. Chem. Geol. 363, 213-228.

Lécuyer, C., Reynard, B., Grandjean, P., 2004. Rare earth element evolution of Phanerozoic seawater recorded in biogenic apatites. Chem. Geol. 204, 63-102.

Liu, A.G.S.C., Seiffert, E.R., Simons, E.L., 2008. Stable isotope evidence for an amphibious phase in early proboscidean evolution. Proceedings of the National Academy of Sciences 105, 5786-5791. https://doi.org/10.1073/pnas.0800884105

Lucas, J., Prevôt-Lucas, L., 1995. Tethyan phosphates and bioproductites. In: Nairn, A.E. (Ed.), The Ocean Basins and Margins. The Tethys Ocean, vol. 8. Plenum Press, pp. 367-391.

Mahboubi, S., Bocherens, H., Scheffler, M., Benammi, M., Jaeger, J.-J., 2014. Was the Early Eocene proboscidean Numidotherium koholense semi-aquatic or terrestrial? Evidence from stable isotopes and bone histology. Comptes Rendus Palevol 13, 501-509. https://doi.org/10.1016/j.crpv.2014.01.002

McArthur, J.M., Howarth, R.J., Shields, G.A., Zhou, Y. 2020. Strontium isotope stratigraphy, Chapter 7. In: Gradstein, F.M., Ogg, J.G., Schmitz, M.D., Ogg, G.M. (Eds.), A Geologic Time Scale, Elsevier B.V., Vol 1 of 2, pp. 211-238.

MacFadden, B.J., Labs-Hochstein, J., Hulbert Jr., R.C., Baskin, J.A., 2007. Revised age of the late Neogene terror bird (Titanis) in North America during the Great American interchange. Geology 35, 123-126.

McLennan, S.M. 1989. Rare earth elements in sedimentary rocks: Influence of provenance and sedimentary processes. In: Lipin RB, McKay AG (Eds.), Geochemistry and Mineralogy of Rare Earth Elements. Review in Mineralogy and Geochemistry vol. 21, pp. 169-200.

Metzger, C.A., Terry, D.O., Grandstaff, D.E., 2004. Effect of paleosol formation on rare earth element signatures in fossil bone. Geology 32, 467-500.

Mohr, B., 1986. Palynologischer Nachweis eines Mangrovenbiotops in der Südatlas-Randzone (Marokko) und seine paläoökologische Bedeuntung. Documenta naturae 33, 20-28.

Mohr, B., Fechner, G., 1986. Eine eozäne Mikroflora (Sporomorphae und Dinoflagellaten-Zysten) aus der Südatlas-Randzone westlich Boumalne du Dadès (Marokko). Berl. Geowiss. Abh. A. 66, 414-481. 
Mouflih, M., 2015. Les phosphates du Maroc central et du Moyen Atlas (Maastrichtien-Lutétien, Maroc): Sédimentologie, stratigraphie séquentielle, contexte génétique et valorisation. Doctorat d'Etat Essciences. Université Cadi Ayyad de Marrakech, Maroc 246 p.

Noubhani, A., Cappetta, H., 1997. Les Orectolobiformes, Carcharhiniformes et Myliobatiformes (Elasmobranchii, Neoselachii) des bassins à phosphate du Maroc (Maastrichtien-Lutétien basal). Systématique, biostratigraphie, évolution et dynamique des faunes. Palaeo-Ichthyologica 8, 1-327.

Office Chérifien des Phosphates, 1989. The phosphates basins of Morocco. In: Notholt, A.J.G., Sheldon, R.P., Davidson, D.F. (Eds.), Phosphates Deposits of the World, Phosphate Rock Resources. Cambridge University Press, Cambridge, pp. 301-311.

Ollivier-Pierre, M.F., 1982. La microflore du Paléocène et de l'Eocène des series phosphatées des ganntour (Maroc). Sci. Géol. Bull. 35 (3), 117-127.

Pearce, N.J.G., Perkins, W.T., Westgate, J.A., Gorton, M.P., Jackson, S.E., Neal, C.R., Chenery, S.P., 1997. A compilation of new and published major and trace element data for NIST SRM 610 and NIST SRM 612 glass reference materials. Geostand. Geoanal. Res. 21, 115-144.

Pearson, P.N., Palmer, M.R., 2000. Atmospheric carbon dioxide concentrations over the past 60 million years. Nature 406, 695-699.

Pereda Suberbiola, X., Bardet, N., larochène, M., Bouya, B., Amaghzaz, M., 2004. The first record of a sauropod dinosaur from the Late Cretaceous phosphates of Morocco. Journal of African Earth Sciences 40, 81-88.

Picard, P., Lécuyer, C., Barrat, J.-A., Garcia, J.-P., Dromart, G., Sheppard, S.M.F., 2002. Rare earth element contents of Jurassic fish and reptile teeth and their potential relation to seawater composition (AngloParis Basin, France and England). Chem. Geol.186,1-16.

Pin, C., Briot, D., Bassin, C., Poitrasson, F., 1994. Concomitant separation of strontium and samariumneodymium for isotopic analysis in silicate samples, based on specific extraction chromatography. Anal. Chim. Acta 298, 209-217.

Rauscher, R., 1985. Les dinokystes, des outils stratigraphiques pour les séries phosphatées. Application aux phosphorides du Maroc. Sci. Géol. Bull. 77, 69-74.

Reynard, B., Balter, V., 2014. Trace elements and their isotopes in bones and teeth: Diet, environments, diagenesis, and dating of archeological and paleontological samples. Palaeogeogr. Palaeoclimatol. Palaeoecol. 416, 4-16

Reynard, B., Lécuyer, C., Grandjean, P., 1999. Crystal-chemical controls on rare earth element concentrations in fossil biogenic apatites and implications for paleoenviromental reconstructions. Chem. Geol. 155, 233-241.

Schubert, A.B, Jahren, A.H., 2012. The effect of atmospheric CO2 concentration on carbon isotope fractionation in C3 land plants. Geochimica et Cosmochimica Acta 96, 29-43.

Secord, R., Wing, L.S., Chew, A., 2008. Stable Isotopes in Early Eocene Mammals as Indicators of Forest Canopy Structure and Resource Partitioning. Paleobiology, 34(2),. 282-300.

Shields, G.A., Webb, G.E., 2004. Has the REE composition of seawater changed over geologic time. Chem. Geol. 204, 103-107.

Simmer, J.P., Hu, Y., Lertlam, R., Yamakoshi, Y., Hu, J.C.C., 2009. Hypomaturation enamel defects in KIk4 knockout/LacZ knockin mice. J Biol Chem 284, 19110-19121.

Snedden, J.W., Liu, C., 2010. A compilation of Phanerozoic sea level change, coastal onlaps, and recommended sequence designations: AAPG Search and Discovery article 40594, http://www.searchanddiscovery.net/documents/2010/40594snedden/ndx_snedden.pdf (accessed October 2020)

Soncini, M.-J., 1990. Palynologie des phosphates des Oulad Abdoun (Maroc). Biostratigraphie et environnements de lab phosphatogenèse dans le cadre de la crise Crétacé/Tertiaire. Université Louis Pasteur, Strasbourg, p. 243. Ph.D. thesis.

Staron, R.M., Grandstaff, B.S., Gallagher, W.B., Grandstaff, D.E., 2001. REE signatures in vertebrate fossils from Sewell, NJ: implications for location of the K-T boundary. Palaios 16, 255-265.

Suarez, C.A., Macpherson, G.L., González, L.A., Grandstaff, D.E., 2010. Heterogeneous rare earth element (REE) patterns and concentrations in a fossil bone: implications for the use of REE in vertebrate taphonomy and fossilisation history. Geochim. Cosmochim. Acta 74, 2970-2988.

Trueman, C.N., Tuross, N., 2002. Trace elements in recent and fossil bone apatite. In: Kohn, M.J., Rakovan, J., Hughes, J.M. (Eds.), Phosphates: Geochemical, Geobiological, and Materials Importance. Review in Mineralogy and Geochemistry vol. 48, pp. 489-521.

Trueman, C.N., Benton, M.J., Palmer, M.R., 2003. Geochemical taphonomy of shallow marine vertebrate assemblages. Palaeogeogr. Palaeoclimatol. Palaeoecol. 197, 151-169. 

mineral: a natural cation exchange system. Palaeogeogr. Palaeoclimatol. Palaeoecol. 310, 124-132.
Tütken, T., Vennemann, W.T., Janz, H., Heizmann, E.P.J. 2006. Palaeoenvironment and palaeoclimate of the Middle Miocene lake in the Steinheim basin, SW Germany: A reconstruction from C, $O$, and Sr isotopes of fossil remains. Palaeogeography, Palaeoclimatology, Palaeoecology 241, 457-491.

Tütken, T., Vennemann, T.W., Pfretzschner, H.-U., 2008. Early diagenesis of bone and tooth apatite in fluvial and marine settings: constraints from combined oxygen isotope, nitrogen and REE analysis. Palaeogeogr. Palaeoclimatol. Palaeoecol. 266, 254-268.

Tütken, T., 2014. Isotope compositions (C, O, Sr, Nd) of vertebrate fossils from the Middle Eocene oil shale of Messel, Germany: Implications for their taphonomy and palaeoenvironment. Palaeogeography, Palaeoclimatology, Palaeoecology 416, 92-109

Vail, P.R., Audemard, E., Bowman, S.A., Eisner, P.N., Perez-Crus, C., 1991. The stratigraphic signatures of tectonics, eustasy and sedimentology-an overview, in Einsele, G., Ricken, W., and Seilacher, A., eds., Cycles and events in stratigraphy: Springer-Verlag, Berlin, p. 617-659.

van der Meer, D.G., van den Berg van Saparoea, A.P., van Hinsbergen, D., van de Weg, R., Godderis, Y., Le Hir, G., Donnadieu, Y., 2017. Reconstructing first-order changes in sea level during the Phanerozoic and Neoproterozoic using strontium isotopes: Gondwana Research 44, 22-34.

van Hinsbergen, D.J.J., de Groot, L.V., van Schaik, S.J., Spakman, W., Bijl, P.K., Sluijs,A., Langereis, C.G., Brinkhuis, H., 2015. A paleolatitude calculator for paleoclimate studies. PLoS ONE 10, e0126946-21. http://dx.doi.org/10.1371/journal.pone.0126946

Wei, L., Yan, C., Ye, B., Guo, X., 2008. Effects of Salinity on Leaf $\delta^{13} \mathrm{C}$ in Three Dominant Mangrove Species along Salinity Gradients in an Estuarine Wetland, Southeast China. J. of Coastal Research, 241, $267-272$.

White, W.M., 1998. The Ocean as a Chemical system. Geochemistry, an on-line textbook, vol. 15. pp 645-701.

Yans, J., Amaghzaz, M., Bouya, B., Cappetta, H., lacumin, P., Kocsis, L., Mouflih, M., Selloum, O., Sen, S., Storme1, J.-Y., Gheerbrant, E., 2014. First carbon isotope chemostratigraphy of the Ouled Abdoun phosphate Basin, Morocco; implications for dating and evolution of earliest African placental mammals. Gondwana Research 25, 257-269.

Zazzo, A., Lécuyer, C., Mariotti, A., 2004. Experimentally-controlled carbon and oxygen isotope exchange between bioapatites and water under inorganic and microbially-mediated conditions: Geochimica et Cosmochimica Acta 68, 1-12, doi:10.1016/S0016 -7037 (03) 00278-3.

Žigaitè, Ž., Fadel, A., Blom, H., Pérez-Huerta, A., Jeffries, T., Märss, T., Ahlberg, P.E., 2016. Palaeoenvironments revealed from rare earth element systematics in vertebrate bioapatite from the Lower Devonian of Svalbard. In: In: Melchin, M., Jisou, J. (Eds.), Canadian Journal of Earth Sciences, vol. 53. pp. 788-794 8.

Žigaitè, Ž., Qvarnström, M., Bancroft, A., Pérez-Huerta, A., Blom, H., Ahlberg, P.E., 2020. Trace and rare earth element compositions of Silurian conodonts from the Vesiku Bone Bed: Histological and palaeoenvironmental implications. Palaeogeography, Palaeoclimatology, Palaeoecology 549109449. 
1001

1002

1003

1004

1005

1006

1007

1008

1009

1010

1011

1012

1013

1014

1015

1016

\section{Figure captions}

Figure 1 (a) The origins of the fossils from the Ouled Abdoun Basin in Morocco studied here. Quarries in the Sidi Daoui and Sidi Chennane (grey boxes) are the regions from which most of the remains were reported. The background geochemical data are also derived here (see Figure 5). (b) Generalized stratigraphic log of the Ouled Abdoun Basin. Note the major bone beds and the mammal-bearing layers, however, many specimens were obtained without an exact stratigraphic position. Abbreviation: $\mathrm{BCbb}$ - big coprolite bone bed. c) Examples of some of the mammals found in the Ouled Abdoun phosphate series, successively from lowermost to uppermost levels: Eritherium azzouzorum (skull rostrum with teeth in ventral view; Gheerbrant, 2009), the earliest known proboscidean, lower bone bed of bed Ila, Selandian; Phosphatherium escuilliei (skull in ventral view; Gheerbrant et al., 2005), early proboscidean, intercalary beds II/I, early Ypresian; Daouitherium rebouli (lower jaw ML 20269987 in lateral view), the first large proboscidean (Gheerbrant et al., 2002), upper phosphates levels (bed 0?), middle Ypresian; Stylolophus major (maxillary with teeth; Gheerbrant et al., 2018, 2020), earliest known embrithopod with S. minor, uppermost phosphates levels, bed 0 or sillons, middle Ypresian.
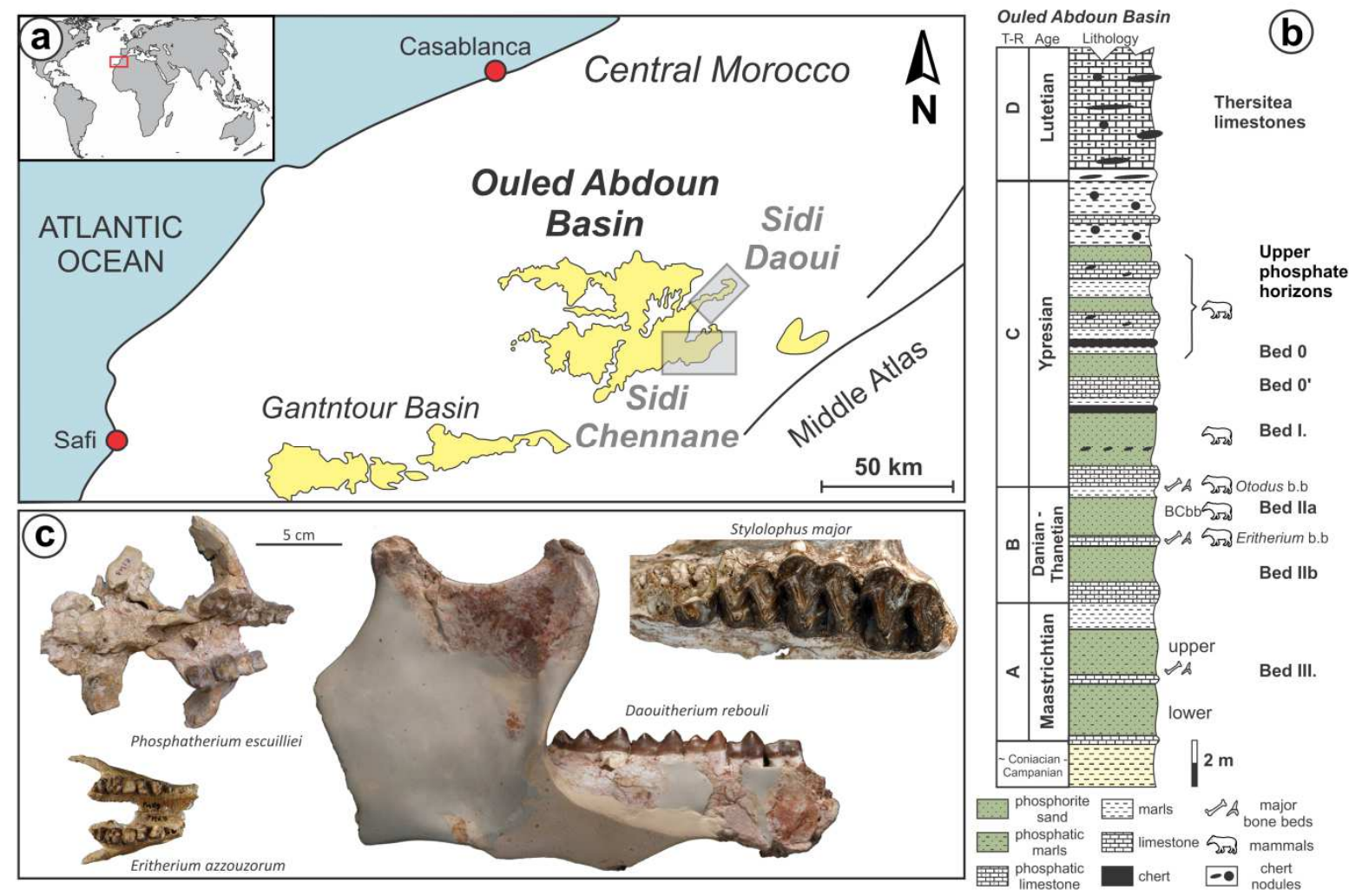
1019 Figure 2 Major element compositions of selected mammals, shark teeth and coprolites from 1020 the Ouled Abdoun Basin.

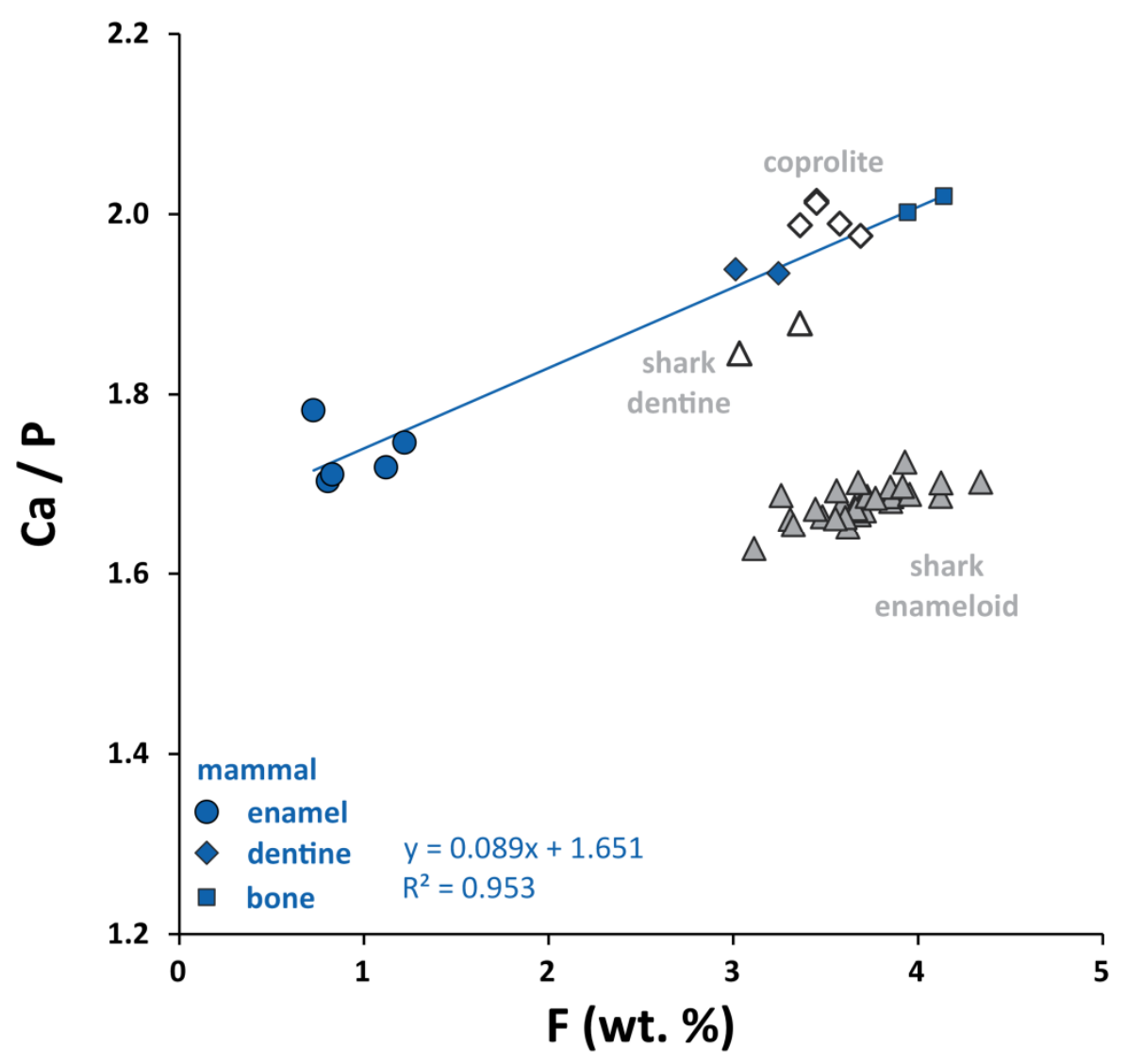

1021

1022 
Figure 3 Boxplots of selected trace elements. The label "Mammal" reflects data directly analyzed from the mammal remains (tooth enamel, dentine, and bone), while the label "Matrix" refers to data from fossils derived from the sediment matrix (shark tooth enameloid, dentine, and coprolite) related to the mammals. Student's t-tests were performed to check for statistical differences among these groups (Supplementary Material Table-4). Note that, Sr content in shark tooth enameloid and Ba content in mammal enamel are significantly higher than in the rest of the materials (marked red). Zinc concentration is the highest in enamel and enameloid, and both differ significantly from the coprolite data, whereas shark tooth enameloid is also statistically dissimilar from the dentine and bone data. The REE concentration is the lowest in the enamel/enameloid with significant differences from the other materials (marked red). Distribution of $U$ content among the materials mimics more or less that of the REEs, however with various significances among the different groups (see Supplementary Material Table-4). The $\mathrm{Ce} / \mathrm{Ce}$ * data yielded no statistical differences among the groups.

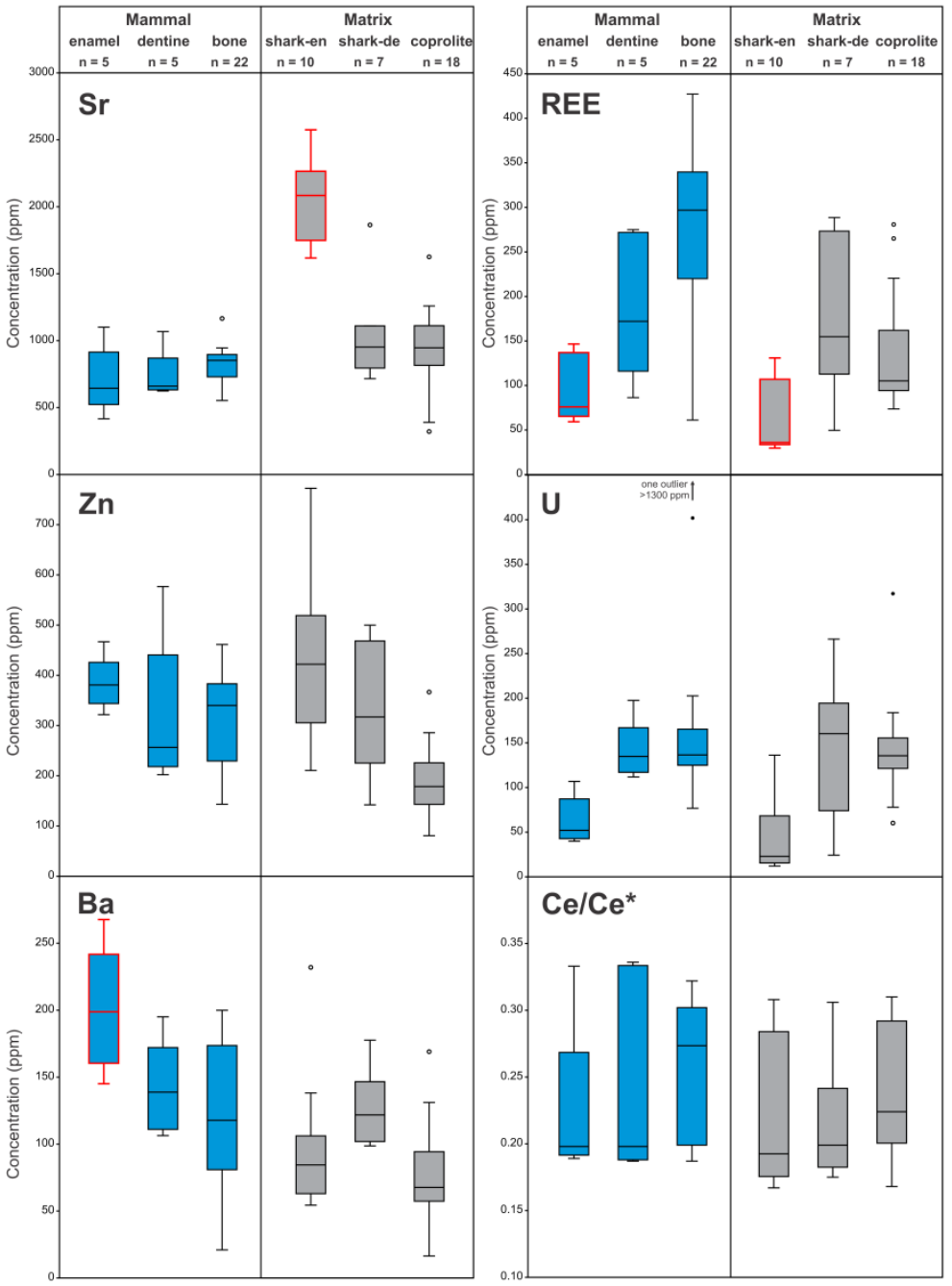


Figure $4 \mathrm{Ce} / \mathrm{Ce}$ * and $\mathrm{Pr} / \mathrm{Pr} *$ variations among the samples. (a) Background data from the

1039 Ouled Abdoun Basin derived from fish teeth, bones and coprolites (Kocsis et al., 2016). Note

1040 the time-wise trending of the samples in the basin. The few overlapping samples show meaningful stratigraphic separation, see Figure 5. (b-d) Comparisons of the Paleocene and

1042 Eocene background data with the various mammal groups being investigated. Note that the 1043 samples are better separated by $\mathrm{Ce} / \mathrm{Ce}^{*}$ than by $\mathrm{Pr} / \mathrm{Pr}^{*}$. Inset figures display examples of 1044 PAAS normalized REE patterns. Note the similarities in the REE distributions among the 1045 various materials (a) and taxa (b-d).
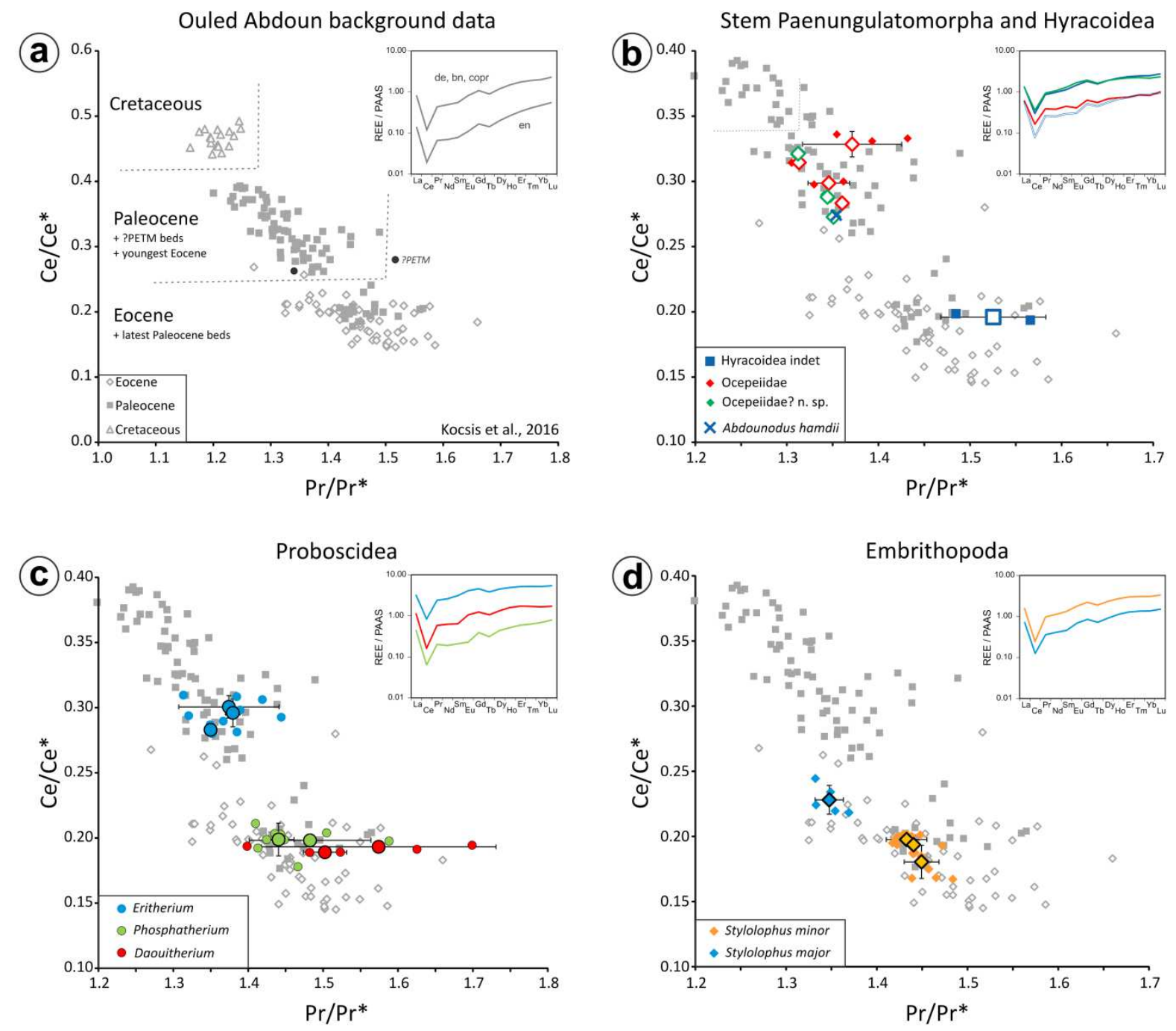

1046 
Figure 5 Stratigraphic variation of $\mathrm{Ce} / \mathrm{Ce}$ in the Ouled Abdoun Basin based on Kocsis et al.

1049 (2016) and new data provided in Supplementary Material Table-1. Note that the data are 1050 derived from two quarrying areas: Sidi Daoui and Sidi Chennane. Based on the variation of 1051 the $\mathrm{Ce} / \mathrm{Ce}^{*}$ values the section is divided into 10 horizons (see text and Table 3). Int. III/II and 1052 Int. II/I refer to intercalary beds respectively between Bed III and II, and, Bed II and I. Note 1053 that the $\mathrm{Ce} / \mathrm{Ce}$ * data for the few mammal remains (S. minor and E. azzouzorum) with known 1054 stratigraphic origins fit well with the background dataset.

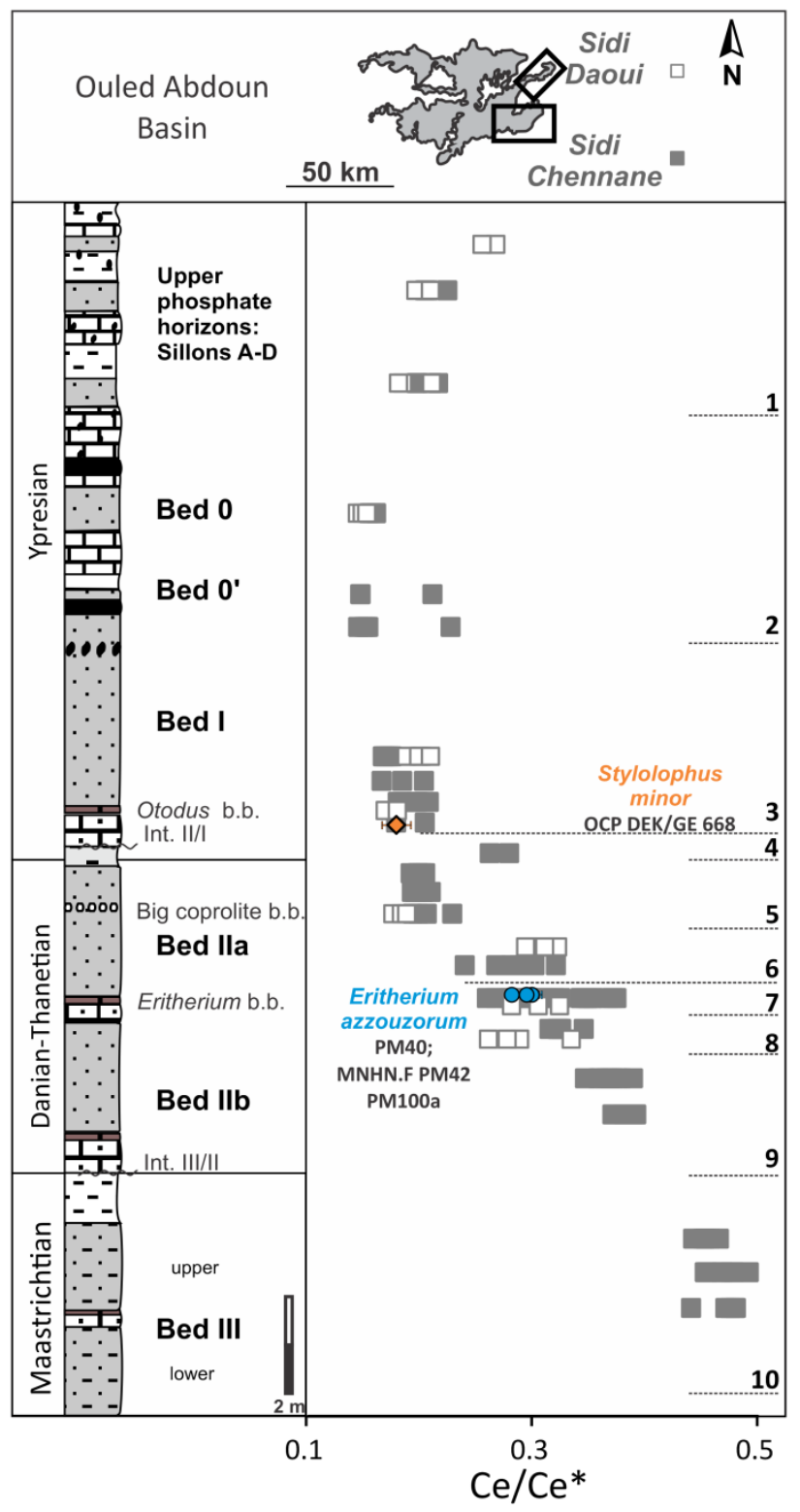


Figure 6 Stratigraphic origins of the mammal remains from the Ouled Abdoun Basin studied here, inferred from comparisons of their mean $\mathrm{Ce} / \mathrm{Ce}$ * ratios with the average stratigraphic values of the 10 chemostratigraphic horizons (see also Table 3). Note that the thickness of the lines reflects different probabilities. Where only one specimen was analyzed a dashed line is used. In some cases, the composition of the sediment matrix and the selachian fauna 1062 (i.e., sharks and rays) give further clue about the possible provenance. The vertical extension of the bar across several levels for some species does not necessarily indicate a wide stratigraphic range, but the best probability of their stratigraphic origin following the $\mathrm{Ce} / \mathrm{Ce}$ * chemostratigraphy. However, when other factors (e.g., the sedimentary matrix and related fauna) are considered, their provenance can be reduced further, as indicated by the grey background. The yellow background is used for those fossils whose stratigraphic origin was known previously (see Figure 5).

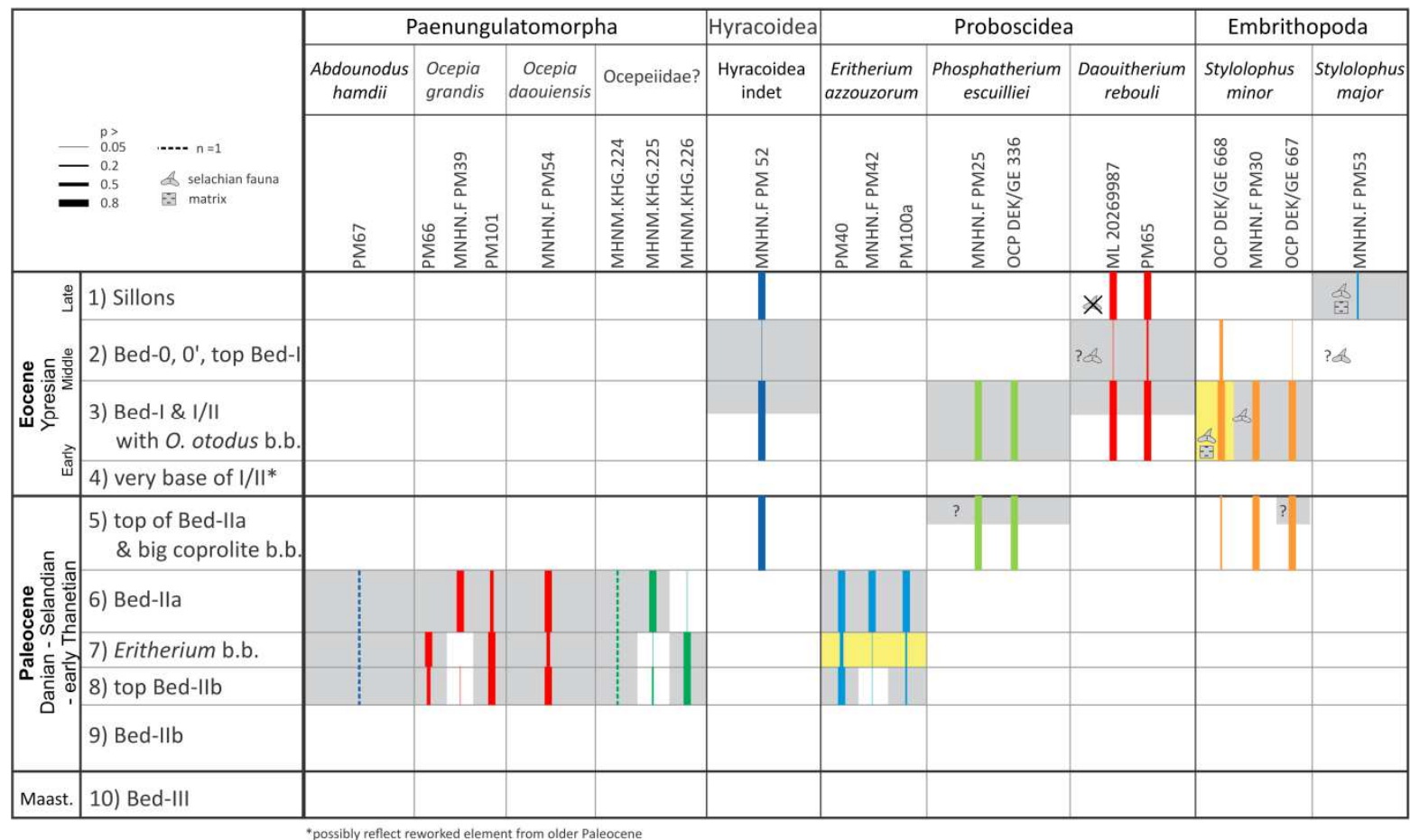


1071 Figure 7 Strontium isotope variation and its comparison with the global Sr-evolution curve

1072 (McArthur et al., 2020). Dashed lines represent the 95\% confidence limits. (a) Mammal

1073 samples with circles. Note that these data are well above the open ocean Sr-evolution curve

1074 and the ${ }^{87} \mathrm{Sr} /{ }^{86} \mathrm{Sr}$ ratios decrease from enamel to bone. The enamel end-members could

1075 reflect in-vivo Sr ratios, while the dentine and bone show various interactions with

1076 seawater. Triangles are individual shark tooth enameloid analyses from the Ouled Abdoun

1077 (OA) and Ganntour (GB) basins. The data are plotted according to stratigraphic occurrence

1078 and predicted ages (see Supplementary material Table-5). (b) Layer averaged ${ }^{87} \mathrm{Sr} /{ }^{86} \mathrm{Sr}$ ratios

1079 of shark tooth enameloid from the previous graph for the phosphate series (triangles) and

1080 foraminifera Sr-isotope data from Hodell et al. (2007). The average data are plotted

1081 according to ages derived from McArthur et al. (2020). Note that the latest Cretaceous and

1082 most of the Paleocene are above the Sr-evolution curve.
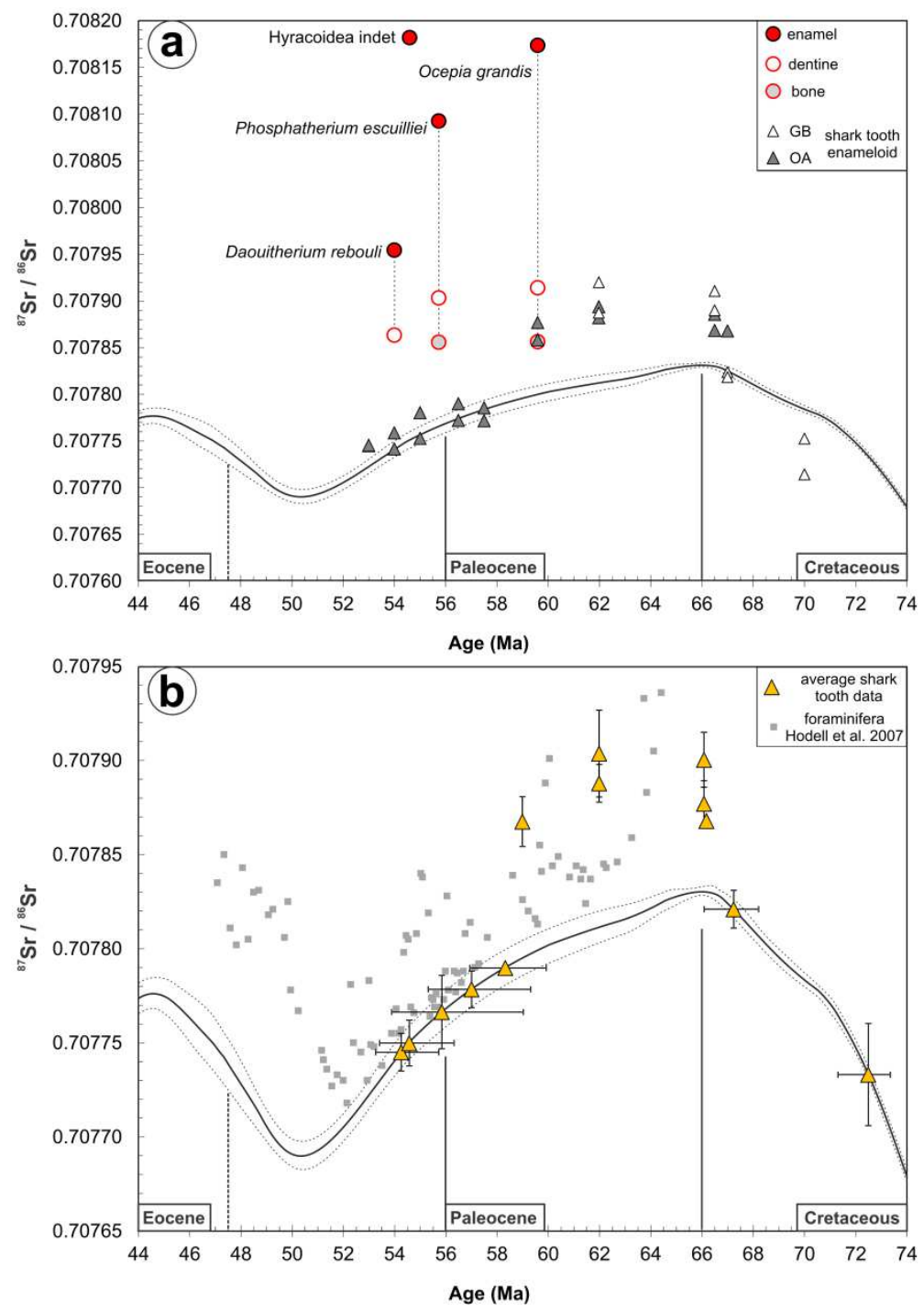
1084

1085

1086

1087

1088

1089

1090 seawater

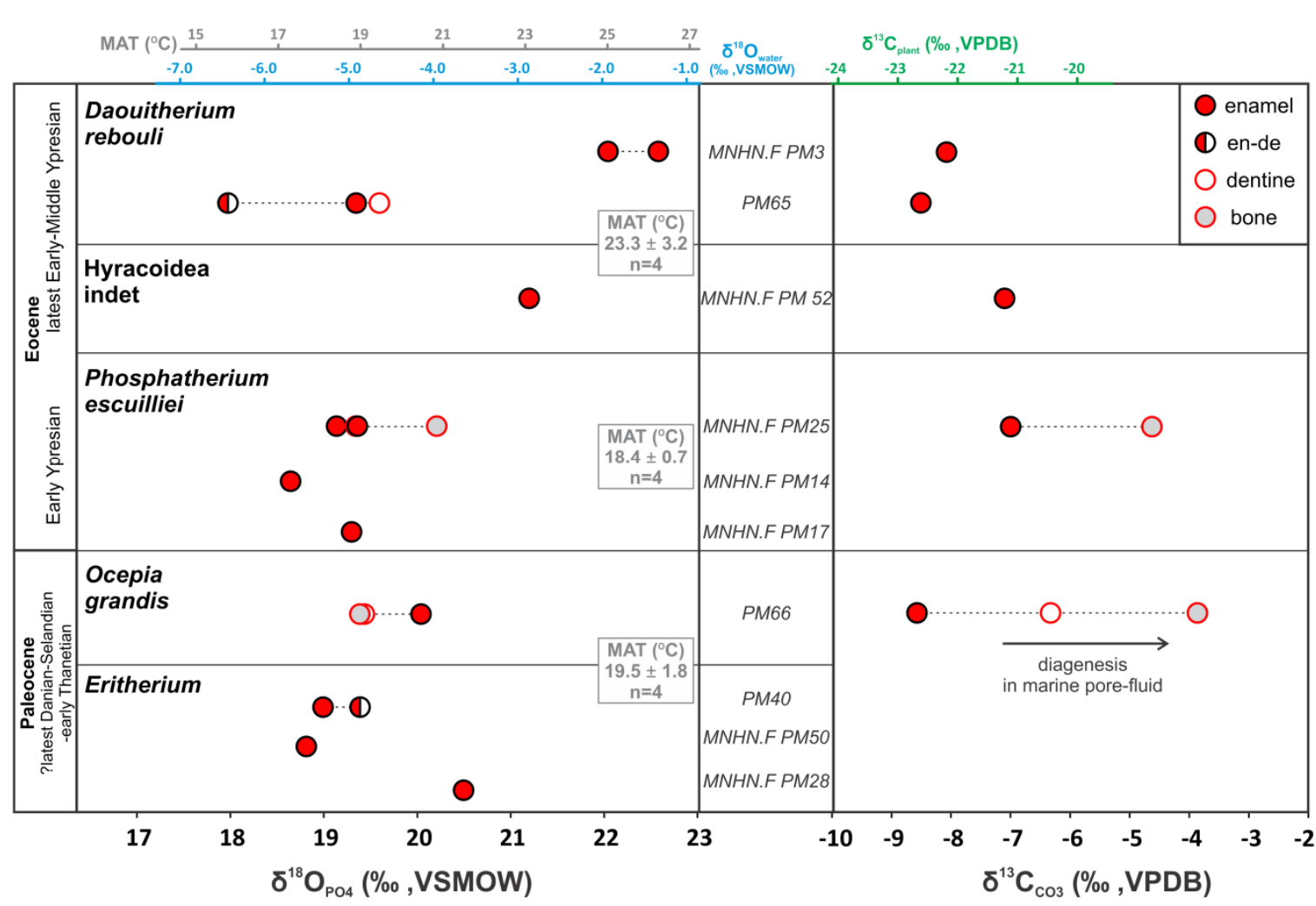

1091

Figure 8 Stable isotope compositions of selected mammal taxa and related ecological and environmental parameters. (a) Oxygen isotopic composition of phosphate. The derived isotopic composition of the ingested water and the mean annual temperature (MAT) are calculated based on Amiot et al. (2004). (b) Carbon isotopic composition of the structural carbonate and the calculated plant diet isotopic composition after Kohn and Cerling (2002). Note the increasing trend from enamel to bone, indicating an alteration in the presence of 
1094 Table 1 The mammal remains investigated, and related analyses. Note the uncertain 1095 stratigraphic origin, column Locality/Layers, indicated by question marks. Abbreviations: en 1096 - enamel, de - dentine, th - tooth, sh - shark tooth, ra - ray tooth, copr - coprolite, pel 1097 pellets.

1098

\begin{tabular}{|c|c|c|c|c|c|c|c|c|c|c|c|c|c|}
\hline \multirow[b]{2}{*}{ Inventory No. } & \multirow[b]{2}{*}{ Order } & \multirow[b]{2}{*}{ Family } & \multirow[b]{2}{*}{ Species } & \multirow[b]{2}{*}{ Locality / Layer } & \multirow[b]{2}{*}{ Age } & \multicolumn{3}{|c|}{ ICP-REE } & \multirow[b]{2}{*}{$\delta^{18} \mathrm{O}_{\mathrm{PO}}$} & \multirow[b]{2}{*}{$8^{13} c-8^{18} 0_{003}$} & \multirow[b]{2}{*}{${ }^{87} \mathrm{Sr} / \mathrm{p} \mathrm{sr}$} & \multirow[b]{2}{*}{ EMPA } & \multirow[b]{2}{*}{ References } \\
\hline & & & & & & specimen & matrix & No. & & & & & \\
\hline MNHN.F PM3 & Proboscidea & Numidotheriidae? & Doouitherium rebouli & above $\mathrm{Cl}$ ? & Ypresian & -1 & - & & & & & & Gheerbrant et al., 2012 \\
\hline PM65 & Proboscidea & Numidotheriidae? & Daouitherium cf. rebouli & above $\mathrm{Cl}$ ? & Ypresian & en, de & . & 2 & + & + & + & + & Gheerbrant et al., 2012 \\
\hline ML 20269987 & Proboscldea & Numldotherildae? & Dooultherfium reboull & co? (selachlans) & Ypresian & & sh, copr & 3 & & & & & \\
\hline MNHN.F PM 52 & Hyracoidea & Indet & Hyracoidea indet & ? & PYpresian & en, de & & 2 & + & + & + & + & unpublished \\
\hline MNHN.F PM53 & Embrithopoda & Stylolophidae & Stylolophus major & sillons? & Ypresian & en\& de & sh (en-de), copr & $2+3$ & & & & & Gheerbrant et al., in press \\
\hline MNHN.F PM 30 & Embrithopoda & Stylolophidae & Stylolophus minor & intercalary 11/1? & Ypresian & bn & sh, copr & $3+2$ & & & & & Gheerbrant et al., 2018 \\
\hline OCP DEK/GE 667 & Embrithopoda & Stylolophidae & Stylolophus minor & intercalarr II/R? & Ypresian & bn & copr & $3+2$ & & & & & Gheerbrant et al, 2018 \\
\hline OCP DEK/GE 668 & Embrithopoda & Stylolophidae & Stylolophus minor & Otodus bonebed, intercalary $11 / 1$ & Ypresian & $\mathrm{bn}, \mathrm{th}$ & sh (en-de), copr & $2+6$ & & & & & Gheerbrant et al., 2018 \\
\hline MNHN.F PM 25 & Proboscidea & Phosphatheriidae & Phosphatherium escuilliei & ? & Ypresian & en, de, bn & sh & $3+1$ & + & + & + & + & Gheerbrant et al., 2005 \\
\hline OCP DEK/GE 336 & Proboscidea & Phosphatheriidae & Phosphatherium esculliliei & ? & Ypresian & & sh (en-de), ra, copr & 4 & & & & & Gheerbrant et al., 2005 \\
\hline MNHN.F PM14 & Proboscidea & Phosphatheriidae & Phosphotherium escullitiei & intercalary $11 / 1$ & Ypresian & & & & + & & & & Gheerbrant et al, 2005 \\
\hline MNHN.F PM17 & Proboscidea & Phosphatheriidae & Phosphatherium escuilliei & intercalary II/I & Ypresian & . & & & + & & & & Gheerbrant et al., 2005 \\
\hline PM67 & Paenungulatomorpha & Indet & Abdounodus hamdii & ? & Paleocene & bn & ${ }^{\circ}$ & 1 & & & & & Gheerbrant $2010^{\circ}$ \\
\hline PM66 & Paenungulatomorpha & Ocepeîidae & Ocepia grandis & ?Clla, ?big coprolite bone bed & Paleocene & en, de, bn & & 4 & + & + & + & + & Gheerbrant et al., 2014 \\
\hline MNHN.F PM39 & Paenungulatomorpha & Ocepelidae & Ocepia grandis & ? & Paleocene & bn & & 2 & & & & & Gheerbrant et al., 2014 \\
\hline PM101 & Paenungulatomorpha & Ocepelidae & Ocepia grandis & ? & Paleocene & bn & & 2 & & & & & unpublished \\
\hline MNHN.F PM54 & Paenungulatomorpha & Ocepelidae & o. doouiensis & ? & Paleocene & & copr, pell & 2 & & & & & Gheerbrant et al., 2014 \\
\hline MHNM.KHG.224 & Paenungulatomorpha & Ocepeildae? & n. sp. & ? & Paleocene & bn & & 1 & & & & & unpublished \\
\hline MHNM.KHG.225 & Paenungulatomorpha & Ocepeildae? & n. sp. & $?$ & Paleocene & bn & & 2 & & & & & unpublished \\
\hline MHNM.KHG.226 & Paenungulatomorpha & Ocepeildae? & n. sp. & ? & Paleocene & bn & & 2 & & & & & unpublished \\
\hline PM40 & Proboscidea & indet. & Eritherium azzouzorum & Eritherium bone bed & Paleocene & - & sh (en-de), copr & 4 & + & & & & Gheerbrant et al., 2012 \\
\hline MNHN.F PM50 & Proboscidea & indet. & Eritherium azzouzorum (juvenile) & Eritherium bone bed & Paleocene & & & & + & & & & Gheerbrant et al., 2012 \\
\hline OCP DEK/GE 498 & Proboscidea & indet. & cf. Eritherium sp. & Eritherium bone bed & Paleocene & & . & . & & & & & unpublished \\
\hline MNHN.F PM28 & Proboscidea & indet. & Eritherium azzouzorum & Eritherium bone bed & Paleocene & . & & & + & & & & Gheerbrant et al., 2012 \\
\hline MNHN.F PM42 & Proboscidea & indet. & Eritherium azzouzorum & Eritherium bone bed & Paleocene & & & 3 & & & & & Gheerbrant et al., 2012 \\
\hline PM100a & Probosscidea & indet. & Eritherium azzouzorum & Eritherium bone bed & Paleocene & bn & sh (en), copr & $1+4$ & & & & & unpublished \\
\hline
\end{tabular}

Table 2 Major element, Sr-isotope ratios, and stable oxygen and carbon isotopic compositions of selected mammal specimens. Abbreviations: en - enamel, de - dentine, ende - enamel dentine transition.

\begin{tabular}{|c|c|c|c|c|c|c|c|c|c|c|c|c|c|c|c|c|c|c|c|c|c|c|c|}
\hline No. & Species & Material & & $\begin{array}{l}\mathrm{CaO} \\
\text { (wt\%) }\end{array}$ & $\begin{array}{l}\mathrm{P}_{2} \mathrm{O}_{5} \\
\text { (wt\%) }\end{array}$ & $\begin{array}{l}F \\
(w t \%)\end{array}$ & $\mathrm{Ca} / \mathrm{P}$ & $\mathrm{n}$ & ${ }^{87} \mathrm{Sr} /{ }^{86} \mathrm{Sr}$ & $\begin{array}{l}\text { ISE } \\
\times 10^{-6} \\
\end{array}$ & Ma & $\begin{array}{l}\delta^{18} O_{\text {po4 }} \\
\text { vsmow }\end{array}$ & std. & $\begin{array}{l}\text { Specimen } \\
\text { average }\end{array}$ & std. & $\begin{array}{l}\text { Taxon } \\
\text { average }\end{array}$ & std. & $\begin{array}{l}\delta^{13} \mathrm{C} \\
\text { VPOB }\end{array}$ & std. ${ }_{\mathrm{ve}}^{8}$ & $\begin{array}{l}8^{18} 0 \\
\text { vPOB }\end{array}$ & $\begin{array}{l}8^{18} 0 \\
\text { vsmow }\end{array}$ & & $\begin{array}{l}\text { Yield } \\
(\%)\end{array}$ \\
\hline \multirow[t]{2}{*}{ MNHN.F PM3 } & Daouitherium rebouli & right $\mathrm{m} 3$ & en & & & & & & & & & 22.0 & 0.1 & & & & & & & & & & \\
\hline & & & en & & & & & & & & & 22.6 & 0.2 & 22.3 & 0.4 & & & -8.1 & $0.1-4$ & -4.2 & 26.6 & & 3.9 \\
\hline \multirow[t]{2}{*}{ PM65 } & Daouitherium rebouli & dP2-4 and M1 & en & 51.7 & 36.7 & 0.73 & 1.78 & 3 & 0.707954 & 3 & 54 & 19.3 & 0.1 & & & & & -8.5 & $0.1-5$ & -5.0 & 25.8 & 0.16 & 6.5 \\
\hline & & & de & 45.1 & 29.5 & 3.01 & 1.94 & 3 & 0.707863 & 3 & 54 & 19.6 & 0.2 & 19.0 & 0.9 & 20.6 & 2.4 & & & & & & \\
\hline MNHN.F PM 52 & Hyracoidea indet & $\mathrm{m} 3$ & en & 50.3 & 37.2 & 0.83 & 1.71 & 3 & 0.708182 & 3 & 58 & 21.2 & 0.1 & 21.2 & 0.3 & 21.2 & & -7.1 & $0.1-3$ & -3.7 & 27.1 & & 6.5 \\
\hline \multirow[t]{2}{*}{ MNHN.F PM25 } & Phosphatherium escuilliei & right p3 & en & 52.1 & 38.7 & 0.81 & 1.70 & 3 & 0.708093 & 5 & 56.5 & 19.4 & 0.1 & & & & & -7.0 & $0.1-4-3-3-3$ & -4.4 & 26.4 & & 5.9 \\
\hline & & & de & 49.4 & 31.2 & 3.95 & 2.00 & 2 & 0.707903 & 3 & 56.5 & 19.3 & 0.2 & & & & & & & & & & \\
\hline MNHN.F PM14 & Phosphatherium escuilliei & $\mathrm{m} 3$ & en & & & & & & & & & 18.6 & 0.2 & 18.6 & 0.3 & & & & & & & & \\
\hline MNHN.F PM17 & Phosphatherium escuilliei & right M2 & en & & & & & & & & & 19.3 & 0.3 & 19.3 & 0.3 & 19.2 & 0.5 & & & & & & \\
\hline \multirow{3}{*}{ PM66 } & Ocepia grandis & tooth fragment & en & 50.3 & 36.5 & 1.22 & 1.75 & 2 & 0.708174 & 3 & 58 & 20.0 & 0.0 & & & & & -8.6 & $0.1-4$ & -4.8 & 26.0 & 0.1 & 6.4 \\
\hline & & & de & 48.9 & 32.0 & 3.25 & 1.93 & 2 & 0.707914 & 4 & 58 & 19.4 & 0.0 & & & & & -6.3 & $0.1-5$ & -5.6 & 25.1 & 0.0 & 5.8 \\
\hline & & bone fragment & bone & & & & & & 0.707856 & 3 & 58 & 19.4 & 0.3 & 19.6 & 0.4 & 19.6 & 0.4 & -3.9 & $0.1-5$ & -5.6 & 25.2 & 0.0 & 6.8 \\
\hline \multirow[t]{2}{*}{ PM40 } & Eritherium & $\mathrm{m} 1$ & en & & & & & & & & & 19.0 & & & & & & & & & & & \\
\hline & & & en-de & & & & & & & & & 19.4 & 0.2 & 19.2 & 0.3 & & & & & & & & \\
\hline
\end{tabular}


1107 Table 3 Tukey's pairwise tests comparing the samples separately with designated horizons.

1108 In the case of Eocene mammals Horizons 1-5, while for the Paleocene taxa Horizons 5-10

1109 were used. Note that only the probability values are listed. Layers with highlighted values

1110 could be considered as a possible provenance for the given mammal fossils, while the

1111 strikethrough numbers indicate invalid scenarios. See also text and Figure 6.

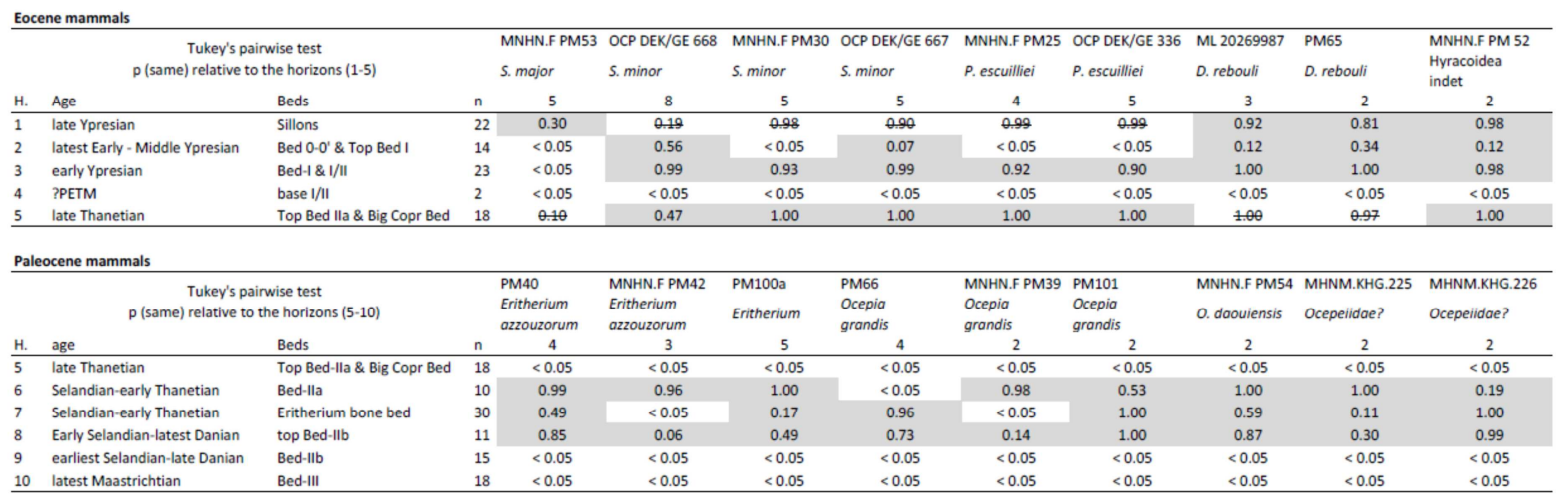

1113 Table 4 Tukey's pairwise tests among the Eocene and Paleocene mammal samples. Note

1114 that S. major is completely different from the rest of the Eocene fossils, while among the

1115 Paleocene samples some of the Ocepeiidae spp. (e.g., PM66 \& MHNM.KHG.226) are

1116 somewhat different from the rest.

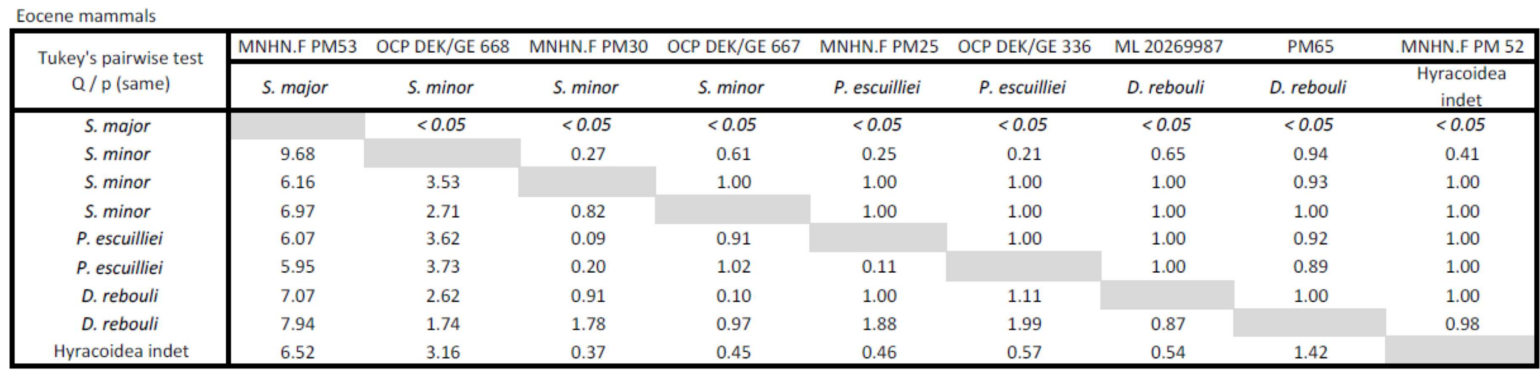

\begin{tabular}{|c|c|c|c|c|c|c|c|c|c|}
\hline \multirow{2}{*}{$\begin{array}{l}\text { Tukey's pairwise test } \\
\text { Q/p (same) }\end{array}$} & PM40 & MNHN.F PM 42 & PM100a & PM66 & MNHN.F PM39 & PM101 & MNHN.F PM54 & MHNM.KHG.225 & MHNM.KHG.226 \\
\hline & E. azzouzorum & E. azzouzorum & Eritherium & O. grandis & O. grandis & O. grandis & O. daouiensis & Ocepeiidae? & Ocepeiidae? \\
\hline E. azzouzorum & & 0.25 & 1.00 & $<0.05$ & 0.28 & 0.55 & 1.00 & 0.64 & 0.12 \\
\hline Eritherium & 1.03 & 2.67 & & $<0.05$ & 0.68 & 0.20 & 1.00 & 0.96 & $<0.05$ \\
\hline O. grandis & 5.78 & 9.48 & 6.81 & & $<0.05$ & 0.53 & $<0.05$ & $<0.05$ & 0.98 \\
\hline 0. grandis & 3.59 & 0.10 & 2.56 & 9.37 & & $<0.05$ & 0.40 & 1.00 & $<0.05$ \\
\hline Ocepeiidae? & 2.66 & 1.04 & 1.63 & 8.44 & 0.94 & 5.52 & 2.29 & & 0.00 \\
\hline Ocepeiidae? & 4.32 & 8.02 & 5.35 & 1.46 & 7.92 & 1.46 & 4.69 & 6.98 & \\
\hline
\end{tabular}




\section{Supplementary Data Tables}

SM Table 1 Supplementary trace element concentration and ratio data from Sidi Chennane and Sidi Daoui areas, focusing on some of the bone beds: the Eritherium bone bed (base Bed Ila), big coprolite bone bed (top Bed Ila), and Otodus bone bed (intercalary II/I). The Ce/Ce* and $\mathrm{Pr} / \mathrm{Pr}^{*}$ ratios are plotted in Figures 4 and 5 as a part of the background dataset.

SM Table 2 Major element compositions of marine remains (shark teeth, coprolites) from the Sidi Chennane quarry of the Ouled Abdoun Basin (see Figure 2 in the paper).

SM Table 3 Trace element concentrations, $\mathrm{Ce} / \mathrm{Ce}{ }^{*}$ and $\mathrm{Pr} / \mathrm{Pr}{ }^{*}$ ratios of the mammal specimens and related matrix from the Ouled Abdoun Basin investigated here (see Figures 3-5 in the paper).

SM Table 4 Student's t-tests on selected geochemical data displayed as boxplots in Figure 3. The six different types of materials studied are mammal enamel, dentine, bones, and shark tooth enameloid, dentine, and coprolites. Significant differences $(p<0.05)$ are marked red, whereas underlined data indicate unequal variances between the compared groups.

SM Table 5 Strontium isotope ratios of shark tooth enameloid from the Ouled Abdoun Basin (see Figure 7 in the paper). Individual analyses are plotted in Figure 7a, while the average data and derived Sr-isotope ages based on McArthur et al. (2020) are in Figure 7b.

SM Table 6 Ten defined chemostratigraphic horizons and their average $\mathrm{Ce} / \mathrm{Ce}$ * values and the related $\mathrm{F}$ and Student's t-test statistics. df- degree of freedom; $\mathrm{p}$ - probability. Underlined $p$-values for the F-test indicate significantly different variances. In this case, the Student's t-tests were performed for unequal variance. The grey p-values for the Student's t-test highlights horizon pairs for which the means of the $\mathrm{Ce} / \mathrm{Ce}$ * values do not differ significantly.

SM Table 7 Recovered selachian fauna and matrix data from a few mammal specimens belonging to the species S. minor, S. major, and D. rebouli. 